\title{
$\begin{array}{llllllllllllllllllllllll}P & R & Z & E & G & L & A & D & Z & A & C & H & O & D & N & I & O & P & O & M & O & R & S & K\end{array}$ ROCZNIK XXXIV (LXIII) ROK 2019 ZESZYT 2
}

\author{
WOJCIECH SKÓRA \\ ORCID: 0000-0003-4940-1086 \\ Akademia Pomorska w Słupsku, Wydział Filologiczno-Historyczny \\ e-mail:wojskimm@gmail.com
}

\section{„BRAMA NA ŚWIAT” I „DWÓJKA”. DZIAŁALNOŚĆ PLACÓWKI POLSKIEGO WYWIADU I KONTRWYWIADU WOJSKOWEGO W GDYNI W LATACH 1933-1939}

Słowa kluczowe: wywiad wojskowy, port w Gdyni, Pomorze, polityka morska, kontrwywiad, Wolne Miasto Gdańsk

Keywords: military intelligence, the port in Gdynia, Pomerania, sea policy, counter-intelligence, the Free City of Gdańsk/Danzig

W latach 1933-1939 w Gdyni działał kilkuosobowy posterunek polskiego wywiadu wojskowego. Choć główny port Drugiej Rzeczypospolitej był „bramą na świat" dla Polaków, prace oficerów nastawione były głównie na sprawy lądowe, lokalne. Personel wywiadowczy działał na obszarze Wolnego Miasta Gdańska i rozpracowywał pobliskie prowincje pruskie, Pomorze Zachodnie i Wschodnie (Provinz Pommern i Provinz Ostpreussen). Wywiad morski prowadzono w niewielkim stopniu, gdyż główne siły niemieckiej marynarki wojennej stacjonowały w dużym oddaleniu od Gdyni. Niniejszy artykuł opisuje uwarunkowania, które przyczyniły się do powołania posterunku gdyńskiego, jego strukturę, personel i realizowane zadania.

Działania polskiego wywiadu wojskowego przeciwko Trzeciej Rzeszy i w Wolnym Mieście Gdańsku mają obszerną historiografię. Pisali na ten temat dawniej Leszek Gondek i Władysław Kozaczuk, a następnie Henryk Ćwięk, 
Edward Długajczyk, Tadeusz Dubicki, Artur Jendrzejewski, Piotr Kołakowski, Robert Majzner, Adam Szymanowicz, Ryszard Techman, Aleksander Woźny i wielu innych. Posterunek wywiadowczy w Gdyni nie doczekał się jednak monograficznego opracowania. Jest to biała plama zarówno w historii Gdyni, jak i służb specjalnych. Z tego powodu artykuł oparty został na spuściźnie dokumentacyjnej Oddziału II Sztabu Głównego Wojska Polskiego. Obszerne i dobrze zachowane akta polskiego wywiadu pozwalają na dokładny opis działań posterunku. Jednak już z oceną efektywności należy się wstrzymać do czasu konfrontacji z ustaleniami historiografii niemieckiej poświęconej wywiadowi. Należy też porównać efekty pracy wywiadu z ówczesnym rzeczywistym stanem rzeczy, czyli potencjałem militarnym Trzeciej Rzeszy. Prace w tym kierunku - ale w odniesieniu do innych obszarów - prowadzili już z powodzeniem Jarosław Centek i Adam Nogaj. W kontekście Pomorza jest to na razie postulat badawczy. Z tego powodu rezultaty prac posterunku gdyńskiego zostały jedynie zasygnalizowane.

\section{Wywiadowczo-kontrwywiadowezy klincz - Wolne Miasto Gdańsk i Gdynia. Przyczyna powołania PO 2 Gdynia}

Postanowienia traktatu wersalskiego w sprawie dostępu Polski do morza były trudnym i niezadowalającym kompromisem. Rozgoryczeni byli Polacy, liczący na Gdańsk, oszukani poczuli się Niemcy, którzy uwierzyli Amerykanom, że kryterium rozstrzygającym o przynależności spornego terytorium będzie narodowość mieszkańców. Odrodzona Rzeczpospolita otrzymała co prawda około 140 km wybrzeża, lecz bez większego portu, bo Puck czy Hel za takowe uchodzić nie mogły. Gdańsk, główny i naturalny port ziem polskich, położony blisko ujścia Wisły (czyli wodnej osi państwa), zyskał status wolnego miasta. Iluzoryczny nadzór Ligi Narodów, słabnącej niemal z roku na rok, powodował stopniową utratę wpływów Warszawy na tym obszarze. Władze gdańskie nie ukrywały swej niemieckiej tożsamości i tęsknot.

Przed władzami Polski dość szybko stanęła konieczność budowy portu zdolnego przyjmować największe statki, by zapewnić łączność z zachodnimi sojusznikami i wymianę handlową, zwłaszcza zbyt śląskiego węgla. Jesienią 1920 roku rząd zdecydował o przyznaniu Ministerstwu Spraw Wojskowych kredytu na kwotę $40 \mathrm{mln}$ marek polskich. Następnego roku w sennej, turystycznej wiosce Gdynia pojawiły się setki robotników, którzy rozpoczęli prace budowlane od wbijania drewnianych pali i sypania głazów do wody. Stałych mieszkańców było zaledwie 1300. Pierwsze, niewielkie statki zacumowały przy drewnianym molo wiosną 
1923 roku. Trzy lata później w Gdyni mieszkało już około 12 tys. osób i władze podjęły decyzję o nadaniu praw miejskich (co nastąpiło 10 lutego) ${ }^{1}$. W 1937 roku w samym porcie pracowało 2550 robotników, zaś liczba pracowników umysłowych w mieście przekroczyła pięć tysięcy ${ }^{2}$. Obroty portu gdyńskiego były wówczas prawie o połowę większe niż Gdańska. Obficie dotowany port państwowy wygrał w rywalizacji z krnąbrnym Wolnym Miastem. Jednak dawało to władzom Gdańska argument, że skoro Polska ma tak dobry port gdyński, dlaczego opiera się przed włączeniem WMG do Rzeszy?

W 1933 roku, gdy utworzono interesujący nas posterunek wywiadowczy w Gdyni, powołano też do życia Dowództwo Obrony Wybrzeża Morskiego, zawiadujące siłami lądowymi na Obszarze Nadmorskim (powiaty morski i kartuski) ${ }^{3} .9$ grudnia poświęcono port gdyński, co oznaczało koniec podstawowego etapu budowy. Tego roku - co można uznać za symboliczne dla znaczenia miasta - uroczyście otwarto dworzec morski. Niemal równocześnie ukazała się broszura Wacława Sieroszewskiego Brama na świat, której tytuł oddawał coraz wyraźniejszy charakter ośrodka. Gdynię zamieszkiwało już około 48 tys. osób nie było to jednak jedno $\mathrm{z}$ wielu miast Rzeczypospolitej. Zbudowane od podstaw i nowoczesne pod wieloma względami, choć z potężnymi enklawami biedy, miasto ruchliwe (trwał nieustanny przepływ ludzi i towarów) ze wszystkimi tego konsekwencjami dla bezpieczeństwa państwa, dobrymi i negatywnymi. W 1937 roku do portu zawinęło 5766 statków kilkudziesięciu bander (najwięcej szwedzkich i niemieckich). Przypłynęło do niego 1718 tys. ton ładunków i ponad 13 tys. pasażerów ${ }^{4}$.

Wyjątkowość Gdyni podnosiło bliskie sąsiedztwo z Wolnym Miastem, które w latach trzydziestych było już w istocie niemiecką enklawą u ujścia Wisły. Naziści, którzy objęli w tym roku władzę w Rzeszy, nie ukrywali, że dążyć będą do włączenia Gdańska do Niemiec. Nie może więc dziwić, że właśnie w 1933 roku utworzono w Gdyni pierwszy stały posterunek polskiego wywiadu

1 M. Kardas, Gdynia i jej władze w latach 1926-1950. Gtówne problemy polskiej administracji publicznej miasta, Toruń 2013, passim.

2 M. Widernik, Rozwój miasta Gdyni w latach 1926-1939, w: Gdynia wczoraj 1926-1986. 60 lat Gdyni, Gdynia 1986, s. 5.

3 W. Tym, A. Rzepniewski, Przygotowania do obrony rejonu Gdyni przez sity Ladowej Obrony Wybrzeża, w: Gdynia 1939. Relacje uczestników walk lądowych, oprac. W. Tym, A. Rzepniewski, Gdańsk 1979, s. 22.

4 Rocznik Morski i Kolonialny 1938, Warszawa 1938, s. 17. 
i kontrwywiadu ofensywnego. Realizacja zadań kontrwywiadowczych w największym porcie polskim należała do wojska. Policja Państwowa była niezbyt liczna, w 1933 roku w całym mieście było 173 policjantów, w tym tylko 5 oficerów (właściwie tak samo kształtowała się liczba oficerów z Oddziału II) 5 .

W istocie sąsiedztwo Wolnego Miasta było główną przyczyną powołania posterunku wywiadu i kontrwywiadu ofensywnego w Gdyni. Gdańsk był miastem cieplarnianym dla działalności szpiegowskiej, czy szerzej ujmując - nielegalnej. Można bez większego błędu podsumować, że około 350 tys. Niemców gdańskich miało do Polski zły stosunek. Nie może więc dziwić przyzwolenie władz WMG na niekorzystne działania wobec Rzeczypospolitej. Działała tam silna placówka niemieckiego wywiadu ofensywnego, Konsulat Generalny ZSRR (realizujący wiele zadań specjalnych) oraz środowiska nacjonalistów ukraińskich, komunistów i „,białych” Rosjan.

Kwintesencję tego zjawiska przedstawiono trafnie w raporcie Samodzielnego Referatu Informacyjnego Dowództwa Floty (SRI DF), placówki pod kilkoma względami bliźniaczej wobec PO 2, napisanego w 1933 roku:

Teren [...] dla wywiadu obcego jest bardzo dogodny ze względu na bliskość $d z i u$ ry gdańskiej, przez którą z wielką łatwością mogą przejeżdżać agenci wywiadu niemieckiego. Pomocnikami w poczynaniach obcego wywiadu są w dużej mierze związki niemieckie, jak: Jungdeutsche Partei, Deutsche Vereinigung itp., które od 1935 r. wykazują wzmożoną działalność. Następnie wywiad obcy posługuje się obecnie szeroko rozgałęzioną siecią konfidentów, posiada kilkanaście lokali konfidencjonalnych w różnych składach i sklepikach na terenie Wolnego Miasta Gdańska, z których urządza skrzynki pocztowe tak, że agenci prawie nie stykają się ze znanymi tutejszemu Samodzielnemu Referatowi Informacyjnemu [Dowództwa Floty - W.S.] przedstawicielami wywiadu niemieckiego w Gdańsku. Między Gdynią a Gdańskiem panuje stale duży ruch i wymiana pracowników, zamieszkałych na terenie WM Gdańska a dojeżdżających do pracy w Gdyni - i odwrotnie. Wymienieni często rekrutują się z informatorów i konfidentów wywiadu obcego. Kontrole paszportowe są na tutejszym terenie niedogodne, niedostateczne i utrudnione. Zdarzają się wypadki, że osobnik jadący z Gdańska na spotkanie do Gdyni, wykupuje bilet do stacji leżących w pobliżu Gdyni (np. Chylonia, Rumia-Zagórze, Reda, Puck, Wejherowo, Hel itp.), przy czym unika kontroli paszportowej, która ma miejsce jedynie w Gdyni, w Orłowie Morskim i częściowo w wagonach kolejowych na stacji Gdynia (w pociągach dalekobieżnych i tranzytowych) - po czym autobusem lub innymi środkami lokomocji dojeżdża do Gdyni. Również wywiad

5 Rocznik Statystyczny Gdyni 1933-1934, red. B. Polkowski, Gdynia 1934, s. 37. 
niemiecki ma ułatwione przenikanie na tutejszy teren drogą morską, wykorzystując do tego celu motorówki, jachty, łodzie i okręty, które przyjeżdżają z terenu WM Gdańska do Gdyni - jako wycieczki. Zanotowano również wypadki przybijania do brzegów mniejszych jednostek morskich w miejscach niestrzeżonych lub słabo strzeżonych. Reasumując - teren tutejszego Samodzielnego Referatu Informacyjnego jest bardzo łatwy do przenikania elementów niepożądanych, a zwłaszcza, że mieszkańcy Gdyni i jej najbliższych okolic przeważnie rekrutują się z ludzi, którzy straciwszy „kredyt moralny” w kraju, przyjeżdżają do Gdyni na „kokosowe interesy". Jest to materiał ujemny, podatny na wszelkie wpływy obce, którym prawnie nic zrobić nie można, a tym samym nie można ich usunąć z tutejszego terenu'

Prawo Wolnego Miasta i dogodne położenie geograficzne czyniły z Gdańska azyl dla osób, które z różnych powodów musiały opuścić okoliczne kraje. Chronili się tu przed prześladowaniami dezerterzy, przemytnicy, fałszerze, pospolici przestępcy i uciekinierzy. Z kontrwywiadowczego punktu widzenia byli to ludzie ,podwyższonego ryzyka”: wykorzenieni, zdeterminowani, pozbawieni środków do życia; nihiliści bądź fanatyczni zwolennicy różnorakich ideologii. Szczególnie groźni byli uchodźcy z terenu Rzeczypospolitej, obywatele polscy, gdyż stanowili źródło werbunku dla wywiadów niemieckiego, radzieckiego, litewskiego lub czechosłowackiego. Niektórzy z nich byli uciążliwi również dla władz WMG. W latach 1921-1936 z Gdańska wysiedlono 2219 obywateli polskich. Z tej grupy około $90 \%$ zostało wcześniej ukaranych przez lokalne sądy ${ }^{7}$.

Tętniący życiem port gdański i sopocki kurort sprzyjały kontaktom z urzędnikami, handlowcami, marynarzami i oficerami różnych armii. Było to miasto ruchliwe, położone na przecięciu dróg łączących Skandynawię, Niemcy, Polskę, kraje bałtyckie i ZSRR. Każdego tygodnia do Wolnego Miasta przybywało ponad tysiąc obcokrajowców z wielu krajów ${ }^{8}$. Niemieckie organizacje cywilno-wojskowe wykorzystywały Gdańsk jako miejsce zaopatrzenia w broń i nawiązywania tajnych kontaktów. Podobnie postępowały organizacje Ukraińców mieszkających w Polsce.

Granica między Gdynią a Wolnym Miastem była łatwa do nielegalnego przekroczenia. Pośrednio potwierdza to niewielka liczba odnotowanych przez

6 Biuro Udostępniania Instytutu Pamięci Narodowej w Warszawie (IPN BU), sygn. 01243/25/1, Kwartalny raport kontrwywiadowczy SRI DF za IV kwartał 1932 r. z 14 I 1933 r.

7 H. Stępniak, Ludność polska w Wolnym Mieście Gdańsku 1920-1939, Gdańsk 1991, s. 157.

8 W rekordowym 1925 r. przyjechało 106 tys. osób (w tym 85\% z Polski i Niemiec). W okresie 22-28 maja 1927 r. przebywało w Gdańsku i zgłosiło się na policję ogółem 1226 obcokrajowców(,Słowo Pomorskie” nr 130, 9 VI 1927 r., s. 7). 
Straż Graniczną nielegalnych prób. W 1932 roku aresztowano z tego powodu 12 osób, rok później tylko 7 osób, ale już w 1934 roku - 27 osób (wzrost można wiązać z postępującą nazyfikacją Wolnego Miasta i restrykcyjnymi przepisami walutowymi wprowadzonymi w WMG, co zwiększyło przemyt) ${ }^{9}$. Można być pewnym, że zdecydowanej większości próbujących nielegalnie przekroczyć granicę - udawało się. Zgodnie z prawem można było to zrobić, okazując jakąkolwiek legitymację osobistą zaopatrzoną w fotografię.

O ile w oczach wojskowych Gdańsk był „ściekiem”, gdzie kumulowały się zjawiska niebezpieczne dla Rzeczpospolitej, o tyle Gdynia była wypieszczonym dzieckiem i dumą. Bliskie sąsiedztwo tak przeciwnych uwarunkowań stwarzało duże napięcie. Dlatego poza działaniami dotyczącymi Wolnego Miasta posterunek wywiadowczy musiał uczestniczyć w ochronie Gdyni. Były dwa główne powody zainteresowania obcych służb tym miastem: port wojskowy i cywilny. W roku powołania do życia posterunku, w porcie wojennym pojawiły się trzy łodzie podwodne sprowadzone z Francji - wiosną 1934 roku polska Morska Flota Wojenna liczyła 20 jednostek o tonażu 24,5 tys. ton ${ }^{10}$.

Gdynia była pod pewnymi względami dogodnym miejscem werbunku dla obcego wywiadu: miasto portowe, turystyczne, przyciągające nadzieją znalezienia pracy lub zrobienia dobrego interesu. W drugiej połowie lat trzydziestych przewijało się przez nią około miliona osób rocznie, w tym 200 tys. cudzoziemców ${ }^{11}$. Stałych mieszkańców było w połowie 1938 roku około 117 tysięcy $^{12}$. Co do znaczenia portu cywilnego w Gdyni dla gospodarki polskiej dość przypomnieć, że w 1936 roku przeszło przezeń 47\% obrotów Rzeczypospolitej z zagranicą.

$\mathrm{Z}$ wywiadowczego punktu widzenia setki tysięcy odwiedzających były szansą, z kontrwywiadowczego - zagrożeniem. Pracy więc nie brakowało, choć najbardziej widoczne efekty w postaci aresztowań szpiegów nie były spektakularne. W 1931 roku w Gdyni aresztowano pod tym zarzutem 2 osoby, w kolejnym - 5 osób, w 1933 i 1934 roku - także po 2 osoby $^{13}$. Liczba zatrzymań nie jest jednak najlepszym punktem odniesienia w tych sprawach, bowiem jest to tylko

9 Rocznik Statystyczny Gdyni..., s. 38.

${ }^{10}$ Tamże, s. 77.

${ }^{11}$ J. Rummel, Sen o Gdyni, w: Brama na świat. Gdynia 1918-1939, oprac. M. Rdesiński, Gdańsk 1976, s. 178 i 180.

${ }^{12}$ Rocznik Morski i Kolonialny..., s. 26.

${ }^{13}$ Rocznik Statystyczny Gdyni..., s. 37. 
jedna z metod działalności kontrwywiadu i wcale nie najlepsza. Werbunek obcym służbom utrudniała niespotykana w Polsce homogeniczność narodowa Gdyni - mieszkało tu stosunkowo niewielu Niemców, Żydów, Rosjan i Ukraińców, czyli przedstawicieli narodowości często wykorzystywanych przez obce służby penetrujące Rzeczpospolitą. W 95\% miasto zamieszkiwała ludność ochrzczona w obrządku rzymskokatolickim ${ }^{14}$.

Gdynię zamieszkiwała społeczność nowa, nieznająca się i słabo zakorzeniona, tworząca dopiero trwalsze struktury. Zapewniało to anonimowość, pomagało w tworzeniu własnej „legendy”, często potrzebnej przy wykonywaniu zadań szpiegowskich. Było to miejsce, w którym obok wielkich sukcesów w skali makro (port, nowoczesna architektura itp.) było wiele goryczy, zawiedzonych nadziei i biedy. Do Gdyni, zwłaszcza w okresie wielkiego kryzysu, przybywali robotnicy $\mathrm{z}$,wnętrza” Polski, skuszeni doniesieniami medialnymi o mieście wielkich szans. Na miejscu rzeczywistość często rozczarowywała. Przyjezdni osiadali w jednym z wielu osiedli biedy, przypominających brazylijskie fawele - domy z dykty, bez podłóg, jedna pompa na 5000 mieszkańców, brak ulic, kanalizacji, oświetlenia, sklepów i chodników, a przede wszystkim - szans na lepsze życie. To była rzeczywistość „dzielnic” Demptowo, Kack Mały, Grabówek, Obłuże, Drewniana Warszawa czy „chińskiej”. Mianem „Budapeszt” określano osiedle nędzy przy ul. Śląskiej, pięć minut piechotą od centrum Gdyni. W połowie lat trzydziestych w 137 „mieszkaniach” wegetowały 634 osoby. Ponad 10\% z nich było chorych na kiłę (w całej Gdyni - około 3000) ${ }^{15}$.

Podejmowaniu współpracy z obcymi wywiadami przez mieszkańców Gdyni sprzyjała wyjątkowa w skali kraju struktura demograficzna tego miasta, wysoki odsetek mieszkańców stanowili ludzie młodzi, co skutkowało rekordowo wysoką liczbą zawieranych małżeństw i rodzących się dzieci. Przyrost naturalny wynosił 21 osób rocznie na 1000 mieszkańców, podczas gdy średnio w Polsce w połowie lat trzydziestych było to 12 osób (w Toruniu 8, w Warszawie 3 osoby). Zjawisku temu towarzyszyło dość wysokie bezrobocie, rosnące nawet po zakończeniu wielkiego kryzysu (w 1937 r. w mieście odnotowano 6194 osoby bez pracy) ${ }^{16}$.

${ }^{14}$ W 1934 r. na 547 zawartych w Gdyni małżeństw 533 zawarły osoby wyznania rzymskokatolickiego, 3 grekokatolickiego, 5 prawosławnego, 8 ewangelickiego i 4 mojżeszowego, zob. Rocznik Statystyczny Gdyni..., s. 21.

${ }^{15}$ M. Wańkowicz, Judym na szczeblu stużbowym, w: Brama na świat. Gdynia 1918-1939, oprac. M. Rdesiński, Gdańsk 1976, s. 158-159.

${ }^{16}$ Rocznik Morski i Kolonialny..., s. 27-28. 
Młodzi, bezrobotni i obarczeni dziećmi ludzie bywali zdesperowani i gotowi przyjąć niemal każde zajęcie, w tym również - szpiegowskie.

Do Gdyni przybywali też „łowcy przygód”, zwabieni treścią podróżniczych powieści, które rozpoczynały się od zaokrętowania bez biletu na statki odpływające do Afryki, Azji czy Australii. Rzeczywistość szybko weryfikowała te miraże. Pasażerów na gapę, wówczas określanych jako „ślepych”, z reguły wykrywano i lądowali na gdyńskim bruku bez środków do życia. Nie była to mała grupa, a noclegi nawet w hotelu robotniczym na Grabówku kosztowały 1 zł dziennie ( $80 \mathrm{gr}$ bez poduszki). To byli ludzie gotowi na wiele, by nie wrócić od razu do domu. Cenne było zarobienie 25 gr za odniesienie koszyka z zakupami, bo można było za to zakupić półtora bochenka chleba ${ }^{17}$. A co dopiero propozycja werbunkowa obcej służby, która za informacje proponowała kilkadziesiąt złotych.

\section{Organizacja, personel i agenci Posterunku Oficerskiego nr 2 w Gdyni}

Od 1919 roku struktury wojskowego wywiadu i kontrwywiadu ofensywnego na terenie Rzeczypospolitej były organizowane na dwóch szczeblach. W Warszawie działała centrala (w najdłuższym okresie był to Oddział II Sztabu Głównego Wojska Polskiego ${ }^{18}$ ) oraz jej ekspozytury terenowe. Te ostatnie uruchamiano zazwyczaj w większych miastach krajowych (np. Poznań, Katowice, Wilno, Lwów). Wyjątkiem było Wolne Miasto Gdańsk (WMG), leżące poza granicami Rzeczypospolitej, gdzie w latach 1920-1930 działała ekspozytura Oddziału II ${ }^{19}$. Ekspozytury tworzyły w mniejszych miastach kilkuosobowe posterunki oficerskie (PO). Działające w kraju miały liczniejszą obsadę i pracowały na poły jawnie (wiedział o nich wąski krąg urzędników i miejscowych funkcjonariuszy), ulokowane za granicą (np. w Królewcu, Szczecinie czy Olsztynie) były zakonspirowane (głównie w konsulatach RP) i jednoosobowe. Kierownicy PO zazwyczaj mieli

${ }^{17}$ Takie realia przedstawiła M. Walicka, Gdynia. Pejzaż sprzed wojny, Gdańsk 1982, s. 84-86.

${ }^{18}$ W latach 1919-1921 był nią Oddział II Naczelnego Dowództwa Wojska Polskiego, później przemianowany na Oddział II Sztabu Generalnego (od grudnia 1928 r. - Sztabu Głównego).

${ }^{19}$ Placówka w Gdańsku, choć występowała pod różnymi nazwami, w zakresie kadrowym i organizacyjnym przez całą dekadę była ekspozyturą. Zob. W. Skóra, Działalność gdańskiej ekspozytury polskiego wywiadu wojskowego w latach 1920-1930 (Pomorze Zachodnie, Prusy Wschodnie i Wolne Miasto Gdańsk), Poznań 2011, passim. Inną ekspozyturą Oddziału II działającą na obszarze formalnie poza jurysdykcją polską była krótko Ekspozytura nr $1 \mathrm{w}$ Wilnie, powołana w sierpniu 1921 r. Jej poprzedniczką była utworzona w 1920 r. Ekspozytura Oddziału II NDWP. W zakresie formalnym Litwa Środkowa weszła w skład państwa polskiego dopiero w kwietniu 1922 r. 
rozpracować przedpole ewentualnych działań militarnych, sięgające kilkadziesiąt kilometrów w głąb sąsiedniego państwa lub - w przypadku umiejscowionych za granicą - obszar w promieniu do około $100 \mathrm{~km}$.

Ekspozytury i ich PO prowadziły przede wszystkim wywiad ofensywny. Zbierały wiadomości o siłach zbrojnych i pozostałych obszarach potencjału przeciwnika. Jednak niektóre z posterunków, ze względu na specyfikę lokalizacji, obarczano wieloma zadaniami z zakresu kontrwywiadu ofensywnego, czyli rozpracowania służb wywiadowczych przeciwnika. Na obszarze północno-wschodnich Niemiec takimi PO były ulokowane w Szczecinie, Królewcu i Gdyni, czyli w pobliżu silnych placówek wywiadu niemieckiego. Były to terenowe placówki wojskowej Abwehry - Abwehrstelle (w skrócie Ast), które początkowo działały w Królewcu, Szczecinie, Berlinie, Dreźnie, Stuttgarcie, Monachium i w Münster). Później ich liczba wzrosła. Zwykle Abwehrstelle podlegały placówki niższego rzędu, odpowiedniki dużych polskich PO, nazywane Nebenstelle (w skrócie Nest).

Placówka Abwehry w Wolnym Mieście (późniejsza nazwa - Nebenstelle Danzig) powstała w 1923 roku. Zakonspirowano ją w kierownictwie policji gdańskiej (Polizei-Präsidium). Pracami Nebenstelle do 1934 roku kierował znający język i polskie realia Oskar Reile, który okazał się ambitnym i zdolnym oficerem ${ }^{20}$. Nie był to „rzemieślnik wywiadu” rutynowo wykonujący zlecone czynności, lecz człowiek o żywym, emocjonalnym stosunku do „,niemieckich kresów wschodnich", uważający zmagania z Polską za rodzaj misji. Rozwój gdańskiej placówki Abwehry stopniowo pogarszał warunki działalności oficerów Oddziału II w Wolnym Mieście i w tym zjawisku trzeba szukać korzeni zarówno likwidacji ekspozytury gdańskiej Oddziału II w 1930 roku, jak i powołaniu Posterunku Oficerskiego 2 w Gdyni (PO 2 Gdynia), z zadaniem kontrwywiadowczego wspierania prac w Gdańsku. Działał on od listopada 1933 do stycznia 1939, nie funkcjonował jednak w odosobnieniu, czyli nie działał sam.

Na terenie województwa pomorskiego w latach trzydziestych istniały trzy placówki polskiego kontrwywiadu wojskowego ${ }^{21}$. Dwie prowadziły rozległy i klasyczny kontrwywiad, jednak ograniczony głównie do obszaru Polski. Były to Samodzielny Referat Informacyjny Dowództwa Okręgu Wojskowego nr VIII

\footnotetext{
${ }^{20}$ Tamże, s. 46. Po odejściu zastąpił go na krótko oficer marynarki Walter Wiebe, a później Siegfried Gerhard Cartellieri, w okresie okupacji zastępca nadburmistrza Gdyni (Gotenhafen).

${ }^{21}$ Zadania kontrwywiadowcze realizowały również - choć w stopniu znacznie węższym aniżeli wojsko - Policja Państwowa i Straż Graniczna.
} 
z siedzibą w Toruniu (SRI DOK VIII) i SRI DF z siedzibą na Oksywiu (Gdynia) 22 . Ich prace uzupełniała Ekspozytura nr 3 Oddziału II Sztabu Głównego Wojska Polskiego, ulokowana od 1930 roku w Bydgoszczy, kierowana przez Jana Henryka Żychonia. Jej zadaniem było prowadzenie wywiadu i kontrwywiadu ofensywnego. Prace przeciwko agendom wywiadowczym - przynajmniej teoretycznie - ograniczały się do rozpoznawania struktur służb przeciwnika. W praktyce jednak ekspozytura bydgoska prowadziła wiele prac z zakresu zwalczania obcych informatorów. Jest to o tyle istotne, że PO 2 Gdynia podlegał ekspozyturze bydgoskiej i był jednym z głównych narzędzi w tym zakresie.

PO 2 powołano w Gdyni kilka miesięcy po objęciu władzy w Rzeszy przez nazistów i tuż po wystąpieniu Niemiec z Ligi Narodów (co nastąpiło w październiku) ${ }^{23}$. Lata 1931-1933 były okresem wyjątkowego napięcia w stosunkach polsko-gdańskich. Ich widownią było głównie forum Ligi Narodów. Prawdopodobnie powołanie posterunku kontrwywiadu ofensywnego (bo taki miał profil działalności przez pierwsze dwa lata) spowodowane było obawą zmiany sytuacji politycznej w Wolnym Mieście. Naziści byli nieobliczalni, a przez to groźni. Nastąpiło co prawda ocieplenie stosunków na linii Warszawa-Berlin, które doprowadziło do deklaracji o nieagresji w styczniu 1934 roku, jednak wystąpienie Niemiec z Ligi Narodów, która formalnie sprawowała polityczną opiekę nad WMG, tworzyło nową sytuację. Obawiano się jej czy wiązano nadzieje? Wydaje się, że raczej to pierwsze.

Pod względem nazwy i - do pewnego stopnia - przydzielonego obszaru rozpracowania PO 2 w Gdyni był kontynuacją PO 2 w Chojnicach, działającego w tym pomorskim mieście w latach $1929-1933^{24}$. Jednak samo oznaczenie „PO 2" może być mylące, gdyż „ciągłość” między tymi posterunkami była

\footnotetext{
${ }^{22}$ Kontrwywiad morski zyskał organizacyjną formę dopiero w 1928 r. Zob. R. Majzner, Organizacja i funkcjonowanie kontrwywiadu morskiego (SRI Dowództwa Floty) w latach 30. XX w. na przykładzie zwalczania niemieckiego szpiegostwa - zarys problematyki, w: Kontrwywiad II RP 1918-1945 (1948), t. 4, red. A. Przyborowska, Warszawa 2017.

${ }^{23}$ Formalne powołanie poprzedził krótki epizod gdyńskiej „podplacówki” PO 4 w Gdańsku, prowadzonej od grudnia 1932 r. przez por. Tadeusza Juliena, a potem przez por. Józefa Robaka, późniejszego pierwszego kierownika PO 2. Służyła ona pomocą posterunkowi w Wolnym Mieście, głównie przy spotkaniach z agentami i werbunkach, które ze względów konspiracyjnych nie mogły odbywać się w WMG.

${ }^{24}$ PO 2 w Chojnicach zlikwidowano na podstawie rozkazu Ekspozytury nr 3 z 26 VI 1933 r. Jego zadania w dużej mierze przejął PO $6 \mathrm{w}$ Poznaniu. O pracach posterunku w Chojnicach zob. W. Skóra, Placówki wywiadu polskiego w Chojnicach. Przyczynek do dziejów Pomorza Zachodniego i Nadwiślańskiego w dwudziestoleciu międzywojennym, Poznań 2011, ss. 458.
} 
niewielka, przede wszystkim miały one zupełnie inną obsadę. Przejęto jednak część wcześniejszych, działających na Pomorzu Zachodnim i północy Niemiec, agentów chojnickiego PO 2.

Do listopada 1935 roku gdyński PO 2 koncentrował się na pracach kontrwywiadowczych związanych z Wolnym Miastem ${ }^{25}$. Dopiero od połowy dekady, w związku z powstaniem Wehrmachtu, zmienił taktykę na działania ofensywne, głównie na terenie Pomorza Zachodniego (czyli wschodniego obszaru Provinz Pommern oraz Grenzmark Posen Westpreussen). PO 2 przydzielono wtedy tereny na północ od linii Człuchów-Pyrzyce-Neubrandenburg, czyli północną część niemieckiego Okręgu Wojskowego nr 2 (Wehrkreis II). W Gdańsku utworzono wówczas nowy PO 5, mający zastąpić posterunek gdyński. PO 2 Gdynia przejął kontakty ofensywne po zlikwidowanym posterunku PO 7/II, korzystającym z usług funkcjonariuszy Straży Granicznej (w lipcu 1935 r.), ale również na wybrzeżu Prus Wschodnich. Niekiedy przeniesienie przez Niemców wartościowego agenta powodowało, że obszar działalności przestawał obowiązywać. Przykładowo, agent PO 2 Gerhard Bach (nr 1210) powołany do służby w Wehrmachcie w październiku 1936 roku służył najpierw w Prusach Wschodnich, zaś w kolejnym roku na lotniskach w Magdeburgu i Brunszwiku. Nadal był ,prowadzony” z Gdyni, choć były to miasta odległe od obszaru przydzielonego PO 2.

Na początku 1939 roku PO 2 został formalnie zlikwidowany. Część personelu połączono organizacyjnie z posterunkiem zakonspirowanym $\mathrm{w}$ gdańskim Komisariacie Generalnym RP (utworzono wówczas w WMG nowy PO 5). Pozostałych przeniesiono do Starogardu, gdzie utworzono nowy PO 4. W Gdyni pozostała „podplacówka” posterunku gdańskiego. Prowadził ją por. Feliks Szalay-Geza ${ }^{26}$.

Posterunek gdyński miał kolejno trzy siedziby. Pierwsza znajdowała się na ul. Podjazdowej 7 (obecnie ul. Dworcowa, budynek stoi do dzisiaj ${ }^{27}$ ). Od lipca 1934 roku PO 2 ulokował się w budynku Miejskich Zakładów Energetycznych przy ul. Mościckich 41A (blisko Komisariatu Głównego Policji Państwowej,

\footnotetext{
${ }^{25}$ Przykładowo, w 1934 r. PO 2 w Gdyni miał ogółem 11 agentów kontrwywiadowczych i 1 agenta wywiadu ofensywnego (Centralne Archiwum Wojskowe [CAW], Oddział II Sztabu Głównego WP [Oddział II SGWP], sygn. I.303.4.6283, Sprawozdanie z działalności PO 2 za rok 1934).

${ }^{26}$ Ł. Ulatowski, Polski wywiad wojskowy w 1939 roku. Struktura organizacyjna, składy osobowe, personel, budzet, mob., Warszawa 2013, s. 91.

${ }^{27}$ Autor dziękuje Janowi Tymińskiemu za tę wiadomość.
} 
na ul. Mościckich 43). Ostatecznie zajął siedem pokoi na VII piętrze reprezentacyjnego gmachu ZUS przy ul. 10 Lutego 24 (w budynku były również pomieszczenia gdyńskiej Izby Przemysłowo-Handlowej, konsulatu niemieckiego, redakcji „Dziennika Gdyńskiego” oraz znana „Cafe Bałtyk” ${ }^{28}$. Budynek ten, stojący do dzisiaj w zewnętrznie niemal niezmienionym kształcie, zaprojektował inżynier Roman Piotrowski. Decydując o lokalizacji, zapewne zakładano, że „najlepiej ukryć igłę w stogu siana". Setki interesantów i klientów odwiedzających jeden z większych biurowców miasta pozwalały zachowań anonimowość. Jeśli obcy wywiad chciał obserwować i sfotografować, kto odwiedza pomieszczenia PO 2, stawał przed zadaniem bardzo trudnym - jak z rzeki ludzi wyłowić konkretne osoby (czy agent poszedł do mocodawców z Oddziału II, czy ze zwykłą sprawą do jednego z wielu urzędów lub bardzo modnej kawiarni). Wyposażenie techniczne PO 2 mieściło się w ówczesnych standardach Oddziału II. W pokojach posterunku były aparaty fotograficzne, sprzęt do wywoływania zdjęć i otwierania listów, broń osobista, radiostacja. Do dyspozycji był też samochód służbowy.

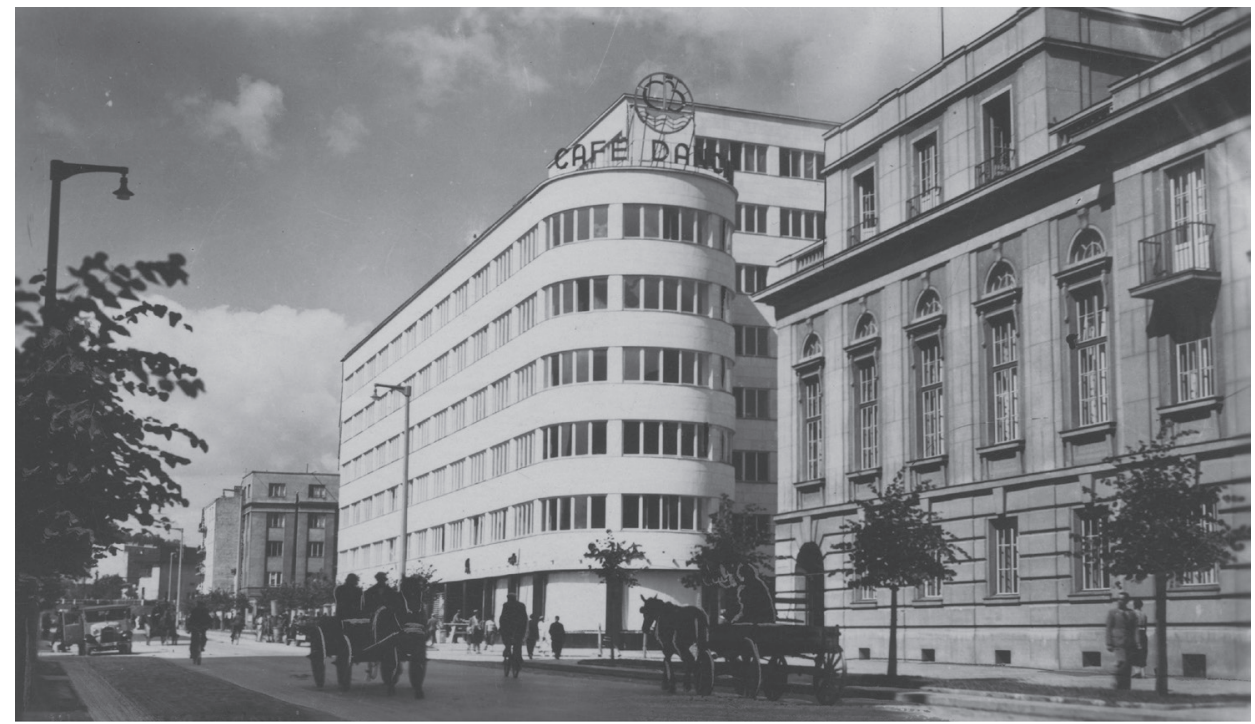

Budynek ZUS w Gdyni przy ul. 10 Lutego 24, gdzie mieściła się siedziba PO 2 (Narodowe Archiwum Cyfrowe, sygn. 1-U-1088)

${ }^{28}$ Wynajęcie tego lokalu od ZUS było kosztowne (390 zł miesięcznie, wraz z obsługą), ale i tak tańsze o $30 \%$ od podobnego metrażu w budynkach prywatnych. W lokalu PO dyżury nocne pełnili naprzemiennie goniec i szofer, uzbrojeni w pistolety. Było to standardowe zabezpieczenie posterunku przed włamaniem obcego wywiadu. 
Centralną postacią posterunku był kierownik. Podlegał służbowo szefowi bydgoskiej ekspozytury, który wydawał mu polecenia i rozliczał z ich wykonania, jednak pod względem dyscyplinarnym był podporządkowany komendantowi miejscowego garnizonu. Zakres obowiązków i uprawnień każdego kierownika posterunku oficerskiego był szeroki. Sprawował on nadzór nad pracami podległego personelu wojskowego, cywilnego i agentów. Wobec podlegających wojskowych miał kompetencje dowódcy kompanii ${ }^{29}$.

Oficerowie, którzy kierowali PO 2, dysponowali dokumentami umożliwiającymi działania w specyficznym świecie ówczesnego „Trójmiasta” polsko-gdańskiego. Posiadali legitymację dyplomatyczną wystawioną przez Komisariat Generalny RP w Gdańsku (zapewniającą w pewnym zakresie immunitet, zwłaszcza przy przekraczaniu granic), legitymację polskiej Straży Granicznej i specjalne zaświadczenie Dyrekcji Ceł, pozwalające uniknąć kontroli.

Żaden z kierowników PO 2 nie był oficerem marynarki wojennej, nie znał specyfiki morza i floty oraz nie miał bliższych rodzinnych związków z Pomorzem. Nieco to dziwi, zważywszy na specyfikę posterunku w Gdyni. Jednak w pewnym zakresie wpasowuje się w ogólną tendencję dotyczącą oficerów Oddziału II działających na obszarze pomorskim w dwudziestoleciu międzywojennym. Szefowie tamtejszych ekspozytur, z Żychoniem na czele, byli przybyszami z obszarów niemających bliższych związków z morzem, Kaszubami, czy nawet szerzej rzecz ujmując - z ziemiami zaboru pruskiego ${ }^{30}$. Cieszyli się za to zaufaniem szefów w Warszawie, między innymi z powodu przeszłości w Legionach Polskich, co uznawano za istotniejsze od pogłębionej wiedzy o terenie działalności operacyjnej.

Pierwszym kierownikiem PO 2 był porucznik (od 1937 kpt.) lotnictwa, obserwator Józef Robak. Kierował nim od 1 listopada 1933 do 19 kwietnia 1934 roku. Potem na ponad rok zastąpił go kpt. Józef Lis, a on sam został drugim

${ }^{29}$ Oznaczało to, że przydzielał zadania i rozliczał z ich wykonania. Sam zaś odpowiadał przed centralą ekspozytury za wykonanie nadsyłanych poleceń z zakresu wywiadu i kontrwywiadu. Do obowiązków kierownika należało zaopatrzenie agentów w fundusze i fikcyjne dokumenty osobiste. Odpowiadał za sprzęt i wydatki posterunku oraz prowadził rozbudowaną dokumentację PO. Posterunek gdyński - podobnie jak pozostałe krajowe PO - prowadził tajny dziennik podawczy, dossier agentów i konfidentów, książkę inwentarzową, książkę służbowych wyjazdów samochodem, ewidencję szyfrów, książkę prac fotograficznych oraz książkę kasową.

${ }^{30}$ Zob. wnioski z tekstu: W. Skóra, Oficerowie wywiadu polskiego na Pomorzu 1919-1939. Sylwetki, kryteria doboru, prawidłowości, w: Kadry decyduja o wszystkim. Studia z zakresu biografistyki wojskowej, red. J. Jędrysiak, D. Koreś, G. Strauchold, K. Widziński, Wrocław 2015, s. 91-123. 
oficerem PO 2, w praktyce zastępcą. Od sierpnia 1935 do lutego 1937 roku ponownie kierował pracami posterunku w Gdyni. Miał więc na tym stanowisku najdłuższy staż. Urodził się w Tarnowie 5 listopada 1899 roku. Jak wielu oficerów Oddziału II służył w Legionach Polskich (od 1916 r.). Jesienią 1918 roku wstąpił do Wojska Polskiego. Służbę w Oddziale II rozpoczął w 1930 roku od struktur kontrwywiadowczych (SRI DOK VII w Poznaniu). Rok później pracował już w PO 3 Grudziądz (i okresowo - w Bydgoszczy), podlegającym ekspozyturze bydgoskiej. W Gdyni działał wywiadowczo od 1932 roku. W opinii przełożonych rzutki, sumienny i ideowy. Pracował pod pseudonimami „Berlinger”, „Kwiatkowski”, „Birnbaum”, „Koepsch”, „Konrad Morski” i „Stanisław Morski”. Po wyjeździe z Gdyni powrócił do Bydgoszczy, gdzie w centrali ekspozytury od kwietnia 1937 roku pracował w referacie kontrwywiadowczym. Od września 1937 roku do marca roku następnego kierował Grupą Wywiadowczą nr 2 ekspozytury $^{31}$. Następnie Robak wykonał dość gwałtowną woltę - opuścił Pomorze i sprawy niemieckie, by od 1938 roku w centrali Oddziału II kierować Podreferatem „Czechy”. W marcu 1939 roku prowadził placówkę wywiadu „LVG” w Sewluszu (obecnie Wynohradiw) na Ukrainie Zakarpackiej. Podczas wojny przez Rumunię trafił do Francji, gdzie służył w lotnictwie. W latach 1940-1942, jako osoba niewygodna polskim władzom w Londynie, został osadzony w obozie odosobnienia Polaków w Rothesay; potem wrócił do służby w wywiadzie. Zmarł na uchodźstwie w Londynie 6 października 1963 roku $^{32}$.

Drugim kierownikiem PO 2 był kpt. Józef Lis, artylerzysta. Objął stanowisko w kwietniu 1934 i piastował do lipca 1935 roku. Urodził się 5 września 1897 roku (ojciec Stanisław). Od 1925 roku w służbie zewnętrznej Oddziału II (nie udało się ustalić zagranicznego miejsca przydziału). Należał do elitarnego, kilkudziesięcioosobowego grona oficerów II Rzeczypospolitej wykonujących zadania wywiadowcze poza granicami kraju, spełniał więc wysokie wymagania z zakresu

\footnotetext{
${ }^{31}$ Grupy Wywiadowcze utworzone po raz pierwszy wiosną 1937 r. były odpowiednikiem posterunków oficerskich ekspozytury, z tą różnicą, że działały na terenie przydzielonym ekspozyturze, bez konkretnego ograniczenia. Nie miały swoich siedzib, korzystały z pomieszczeń PO lub centrali. Przewidywano, że będą one zalążkami nowych PO, które zostaną powołane w przypadku mobilizacji, zob. Ł. Ulatowski, Polski wywiad..., s. 92.

32 T. Dubicki, A. Suchcitz, Oficerowie wywiadu WP i PSZ w latach 1939-1945. Stownik biograficzny, t. 1, Warszawa 2009; t. 2, Warszawa 2011, s. 269-272; D. Dąbrowski, Rzeczpospolita Polska wobec kwestii Rusi Zakarpackiej (Podkarpackiej) 1938-1939, Toruń 2007, s. 293-294.
} 
wykształcenia, umiejętności i cech charakteru ${ }^{33}$. Na początku 1926 roku podjął służbę w strukturach Ekspozytury nr 4 w Krakowie (w latach 1928-1930 kierował PO 2 tej ekspozytury). Posługiwał się nazwiskiem „Lisowski”. Po służbie w wywiadzie - dowódca dywizjonu w 18. Pułku Artylerii Lekkiej (Ostrów Mazowiecka). Podczas wojny dostał się do niewoli radzieckiej (obozy w Starobielsku i Griazowcu). Nie został jednak zamordowany, lecz w październiku 1940 roku trafił do więzienia w Moskwie, gdzie był jedynym z oficerów, których NKWD (wspierane m.in. przez płk. Zygmunta Berlinga) sondowało co do poparcia idei utworzenia oddziałów polskich w ZSRR. Później na krótko osadzono go w „willi rozkoszy (radości)" w Małachówce pod Moskwą, skąd został wywieziony, gdyż nie zgadzał się na współpracę z ZSRR ${ }^{34}$. Był jednym z dwóch oficerów, którzy nie zgodzili się podpisać hołdowniczej deklaracji wobec Stalina. Być może to z nim spotkał się w więzieniu w Saratowie (i innych) Aleksander Wat, co uwiecznił w zapiskach. Parokrotnie przywołał on kapitana dwójki o imieniu Józef, który mu pomógł ${ }^{35}$. Opuścił ZSRR wraz z oddziałami pod dowództwem gen. Władysława Andersa. Walczył w 2 Korpusie Polskim we Włoszech. Po wojnie, już na uchodźstwie, publikował prace poświęcone pobytowi Polaków (głównie wojskowych) w ZSRR. Nagłaśniał też zbrodnie popełnione na polskich jeńcach wojennych ${ }^{36}$.

Ostatnim kierownikiem posterunku był kpt. piechoty Seweryn Dębski. Objął stanowisko w marcu 1937 i zajmował je do końca działalności PO 2, czyli do początku 1939 roku. Urodził się 8 stycznia 1900 roku. Służbę w ekspozyturze bydgoskiej rozpoczął 12 kwietnia 1933 roku. We wrześniu tego roku skierowano go do PO 4 w Gdańsku. Od listopada 1933 do grudnia 1935 roku był eksponentem Oddziału II w Królewcu, zatrudnionym jako urzędnik tamtejszego konsulatu

\footnotetext{
${ }^{33}$ Owe wysokie wymogi w zakresie kwalifikacji szły w latach dwudziestych w parze z niezbyt dobrym traktowaniem tych oficerów, jeśli chodziło o ich karierę zawodową. Wielu z nich służąc za granicą, nie miało przydziału służbowego do jednostek w kraju, co blokowało osiągnięcie wymiaru stażu niezbędnego do awansów. $Z$ tej przyczyny wysoko wykwalifikowani oficerowie wywiadu względnie powoli awansowali, choć trzeba przyznać, że zarobki otrzymywali dość duże, zob. K. Paduszek, Zajrzeć do mózgu Lenina. Wywiad II Rzeczypospolitej a postrewolucyjna Rosja, Łomianki 2016, s. 155.

${ }^{34}$ Katyń. Dokumenty zbrodni, t. 3, Losy ocalatych: lipiec 1940 - marzec 1943, oprac. W. Materski, Warszawa 2001, s. 11.

35 A. Wat, Mój wiek. Pamiętnik mówiony, t. 2, Warszawa 1990, s. 163.

${ }^{36}$ Przykładowo: J. Lis, Geneza tworzenia Polskich Sił Zbrojnych w ZSRR, „Niepodległość” 1948. Autor dziękuje prof. Tadeuszowi Wolszy za wskazanie, podczas obrad konferencyjnych, na tę część biografii mjra Lisa, zob. T. Wolsza, Katyń to już na zawsze katy i katowani. $W$ „polskim Londynie” o sowieckiej zbrodni w Katyniu (1944-1956), Warszawa 2008.
} 
polskiego. Po powrocie do kraju pracował w referacie organizacyjnym ekspozytury bydgoskiej. Gdy zakończył służbę w charakterze kierownika PO 2 Gdynia, od połowy 1939 roku ponownie pracował w bydgoskiej centrali ekspozytury, w referacie organizacyjnym. W Gdyni używał nazwisk „dr Janson”, „Konrad Waligóra” i „Waligórski”.

Pomocniczy personel posterunku tworzyli podoficer, sekretarka i goniec-kierowca. Oprócz oficerów osobą kluczową, w istocie ich zastępcą, był ogniomistrz Józef Lewicki. Utrzymywał on kontakty z agentami, był wtajemniczony w wiele akcji. W PO 2 pracowało też w sumie kilkunastu podoficerów (jako woźnych, radiotelegrafistów, gońców, kurierów, kierowców) oraz pracowników cywilnych (głównie sekretarki) ${ }^{37}$.

Podstawowe prace wywiadowcze i kontrwywiadowcze wykonywali agenci zwerbowani i opłacani przez oficerów Oddziału II. Zasady i tryb ich przyjmowania, struktura narodowościowa, motywacje oraz wynagrodzenia zostały już dość szczegółowo opisane w historiografii. Na potrzeby tego opracowania należy podsumować, że agentami PO 2 byli w zdecydowanej mierze obywatele polscy lub obcy, lecz narodowości polskiej. Przypadki zwerbowania Niemców niemających żadnych związków z polskością należały do rzadkości. Duża część agentów PO 2 została przez Niemców namierzona, osądzona lub przewerbowana po odnalezieniu przez nich dokumentacji pozostawionej przez Oddział II w warszawskim Forcie Legionów we wrześniu 1939 roku.

W czerwcu 1933 roku, po likwidacji chojnickiego PO 2, teczki z dossier agentów posterunku, wraz z poleceniem dalszego ich prowadzenia, przekazano kierownikowi PO 6 w Poznaniu. Po utworzeniu gdyńskiego PO 2 część agentów z okresu „chojnickiego” przeszła pod opiekę kierownika nadmorskiego posterunku. Było ich jednak niewielu, głównie osoby, które na Pomorzu były zaangażowane w akcję „ciotka” (później „wózek”), czyli włamania do niemieckich pociągów tranzytowych, oraz ci, którzy działali na Pomorzu Zachodnim ${ }^{38}$.

${ }^{37}$ Byli to: Maria Chrościechowska (sekretarka w latach 1937-1938), Kociński (kurier do 1938 r.), Agnieszka Kubińska (sekretarka), chor. Jan Lamkowski (od marca 1937 r., jego syn był telegrafistą w gdańskim PO 4), Józef Lewicki (w latach 1934-1936), Seweryn Paczulski (kierowca od 1935 r.), Kazimierz Plaskura (kierowca do czerwca 1935 r.), Franciszek Pluciński (kurier), Alfons Radzicki (woźny do 1935 r.), Piotr Rybicki (woźny), Józef Szymański (radiotelegrafista w latach 1937-1938), Wojciechowski (od 1933 r.), Kazimierz Zwoliński (woźny od 1935 r.).

${ }^{38}$ Akcja „ciotka”, „wózek” była ważną częścią prac PO 2 w Gdyni. Posterunek prowadził akcję perlustracji poczty niemieckiej na trasie od Strzebielina (koło Lęborka) do Malborka. Prace z tego zakresu zostały opisane m.in. w: W. Jastrzębski, Major Żychoń i bydgoska ekspozytura wywiadu, Bydgoszcz 1994; W. Skóra, Placówki wywiadu..., s. 204 i n.; M. Przegiętka, Zainteresowanie 
Wielu agentów kontrwywiadowczych działających w Wolnym Mieście pracowało wahadłowo dla gdyńskiego PO 2 i gdańskiego PO 4. W okresie od listopada 1933 do grudnia 1934 dla PO 2 pracowało ogółem 13 agentów. Z tej grupy tylko jeden (Zygmunt Najdowski) był ofensywny i rozpracowywał umocnienia niemieckie na Pomorzu Zachodnim. W sierpniu 1934 roku dla gdyńskiego PO 2 pracowało ośmiu agentów. Dwa lata później - tylko 6, i w tych granicach zwykle oscylowała liczba informatorów. Dodatkowo wiadomości dostarczali „,przepracowywani” (czyli w trakcie sprawdzania) kandydaci na agentów, których zazwyczaj było kilku, a także przygodni informatorzy, często nieświadomi, komu dostarczają wiadomości. W 1935 roku, w związku ze wspomnianym wcześniej przestawieniem PO 2 na prace ofensywne, znaczną część agentów kontrofensywnych (nr. 1134, 1146, 1171, 1173) przekazano działającemu w Gdańsku PO $4^{39}$.

Jednym z cenniejszych agentów kontrwywiadowczych PO 2 był Brunon Brucki (ps. „Franz Prowe”), zwerbowany przez por. Robaka w 1936 roku. Ważny był jednak nie tyle on sam, co jego tzw. podejście (czyli możliwość kontaktu i wpływu) do szwagierki, Pauliny Tyszewskiej. Jej zwerbowanie było najpoważniejszym sukcesem kontrwywiadowczym PO 2 (i ekspozytury bydgoskiej), gdyż była partnerką życiową zastępcy szefa gdańskiej placówki Abwehry, komandora ppor. Reinholda Kohtza. Pod względem motywacji emocjonalnych sytuacja była korzystna, ponieważ Kohtz był - jak to wówczas określano - „mieszańcem niemiecko-żydowskim" (Mischling ${ }^{40}$ ), za co spotykał go bojkot towarzyski. Swoimi problemami i frustracjami dzielił się więc ze swoją przyjaciółką. Do jej domu przynosił też tajne akta. Tyszewska, wysłuchując zwierzeń partnera, dowiadywała się o akcjach Abwehry w Gdańsku. Po zgodzie na współpracę szerokim strumieniem popłynęły m.in. meldunki o agentach pracujących na niekorzyść Polski, o naradach oficerów wywiadu w Gdańsku, o mieszkaniach konspiracyjnych. W kwietniu 1937 roku Żychoń otrzymał dane (włącznie z kryptonimami) pracowników Abwehry w Gdańsku, Elblągu, Królewcu i Szczecinie. Wiedział

wywiadu polskiego niemieckim wojskowym tranzytem kolejowym przez Pomorze w okresie międzywojennym, w: Studia nad wywiadem i kontrwywiadem Polski w XX wieku, t. 2, red. W. Skóra, P. Skubisz, Szczecin 2015, s. 211-243. Autor przygotowuje obszerny artykuł poświęcony tej akcji.

${ }^{39}$ PO 4 w Gdańsku był obok poznańskiego PO 6 najważniejszym posterunkiem oficerskim Ekspozytury nr 3 w Bydgoszczy. Można nawet zaryzykować tezę, że najważniejszym z powodu znaczenia spraw gdańskich dla Rzeczypospolitej.

${ }^{40}$ Według jednej z przyjętych w 1935 r. ustaw norymberskich i przepisów wykonawczych mieszańcem żydowskim była osoba mająca wśród krewnych wstępnych II stopnia (dziadków) jedną lub dwie osoby narodowości żydowskiej. 
też, jakie wzburzenie zapanowało w wywiadzie niemieckim po serii wpadek na Wybrzeżu. Do Gdańska tego roku przyjechał Wilhelm Canaris, by zmobilizować swoich oficerów do wykrycia przecieku, jednak bez powodzenia ${ }^{41}$.

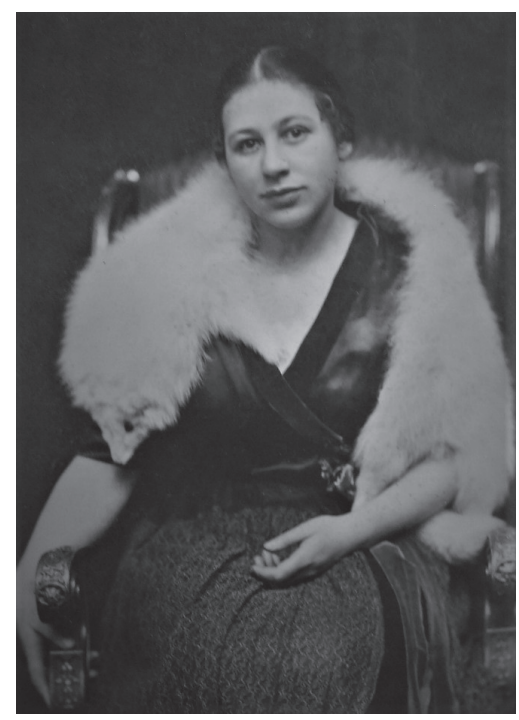

Paulina Tyszewska w 1931 roku (ze zbiorów autora)

Posterunek oficerski w Gdyni w 1935 roku przeznaczał miesięcznie od 1000 do 2800 zł na opłacenie agentów, czyli kwoty podobne do wydatków innych PO ekspozytury bydgoskiej. Przykładowo, agent nr 1137, Franz Palatz (Franciszek Pałac), był Polakiem mieszkającym w Niemczech. Dostarczał informacji o umocnieniach i lotniskach na Pomorzu Zachodnim (m.in. wiele fotografii, głównie z obszaru Szczecinek-Wałcz, gdzie podróżował motocyklem), o życiu gospodarczym niemieckich powiatów wschodnich, organizacji tamtejszej policji i służb granicznych. Ponieważ pracował równomiernie, a ekspozytura oceniała wysoko jego materiały, otrzymywał miesięcznie 250-300 zł, czyli kwotę poważną, równowartość dwukrotnych zarobków robotniczych w Polsce. Ogółem otrzymał

${ }^{41}$ Tyszewska i małżeństwo Bruckich zapłacili za współpracę z ekspozyturą cenę najwyższą. Aresztowano ich w grudniu 1939 r., byli więc jednymi z pierwszych ofiar odnalezienia przez Niemców akt Oddziału II po klęsce wrześniowej w warszawskim Forcie Legionów. Zostali ścięci w 1941 r. Według danych niemieckich w 1938 r. w więzieniach polskich znajdowało się 16 agentów Nebenstelle Danzig aresztowanych w wyniku „zdrady wewnętrznej”, czyli informacji od Tyszewskiej. Zob. L. Gondek, Wywiad polski w III Rzeszy 1933-1939. Zarys struktury, taktyki i efektów obronnego działania, Warszawa 1982, passim. 
1380 zł. Oficer sprawujący opiekę podkreślił, że „wartość agenta jest znacznie większa w stosunku do otrzymanego wynagrodzenia"’2.

Podsumowując, w latach 1933-1938 dla PO 2 Gdynia pracowało co najmniej 37 agentów (tylu udało się odnotować, wraz z ich danymi). Prawdopodobnie było ich więcej, bo w grupie tej była spora zmienność. Dalszych kilkudziesięciu było kandydatami na agentów, lecz albo się rozmyślili, albo oficerowie uznali ich za zbędnych (najczęściej z powodu „niskiej inteligencji”, lenistwa lub oszustw). Oczywiście siatka agentów PO 2 była częścią większego systemu, dynamicznie się zmieniającego. W 1933 roku ekspozytura bydgoska odnotowała zatrudnienie 34 oraz odejście lub zwolnienie 50 agentów ${ }^{43}$.

Zgodnie z poleceniem szefa ekspozytury bydgoskiej w drugiej połowie lat trzydziestych PO 2 zostało zobowiązane do ulokowania agentów-rezydentów w ważniejszych miastach garnizonowych Pomorza Zachodniego. Nie w pełni sprawdzalne wiadomości wskazują, że udało się ich umieścić (zapewne czasowo) w Wałczu, Złotowie, Sławnie, Koszalinie i Kołobrzegu.

Od 1937 roku Ekspozytura nr 3 Oddziału II w Bydgoszczy przystąpiła do zagęszczania i stabilizacji sieci wywiadowczej na pograniczu polsko-niemieckim poprzez przydział ziemi zaufanym osobom, zwykle byłym wojskowym, funkcjonariuszom Straży Granicznej lub policji. Osadzano ich w miejscach istotnych z punktu widzenia rozpoznania, najczęściej przy węzłach komunikacyjnych i przejściach granicznych. Warunkiem uzyskania ziemi było podpisanie zobowiązania do „bezinteresownej współpracy” z wywiadem. Określano ich jako „mężów zaufania", ale kierownicy posterunków oficerskich, którym podlegali na zasadzie terytorialnej, zakładali im dossier jak dla zwykłych agentów. Preferowano osoby znające język niemiecki. Wykorzystywano ich w różny sposób. Niektórzy prowadzili werbunek współpracowników, inni dostarczali informacji z terenów położonych tuż za granicą, niektórzy spełniali rolę ,skrzynek pocztowych”, czyli pośredniczyli w korespondencji między oficerami a agentami. Najinteligentniejszych szkolono w obsłudze aparatów fotograficznych i angażowano jako „pełnych” agentów. Ich siatkę przygotowywano zapewne w ramach przygotowań wojennych.

${ }^{42}$ CAW, Oddział II SGWP, sygn. I.303.4.6167, Raport finansowy PO 2 dla ekspozytury bydgoskiej z 14 II 1936 r.

${ }^{43}$ CAW, Oddział II SGWP, sygn. I.303.4.2214, Uwagi do sprawozdania z planu pracy dla PO Ekspozytury nr 3 w Bydgoszczy za rok 1933 z 15 II 1934 r. 
Na obszarze prac gdyńskiego PO 2 jesienią 1937 roku ulokowano sześciu osadników, w tym aż pięciu na obszarze powiatu chojnickiego ${ }^{44}$.

\section{Główne zakresy działalności PO 2 Gdynia}

Jak już wspomniano, do listopada 1935 roku gdyński posterunek koncentrował się na pracach kontrwywiadowczych związanych z Wolnym Miastem. Wraz z gdańskim PO 4 tworzył swoisty duet, uzupełniając i zabezpieczając jego działania na obszarze krajowym. Wspólnie ,prowadzono” wiele afer, planowano, wymieniano się agentami, użyczano pomieszczeń i sprzętu. W tym układzie gdyński PO 2 był spokojną przystanią dla pracującego w warunkach „frontowych” PO 4. Granica nie była poważną przeszkodą: codziennie między miastami kursowało około 16 pociągów, czas przejazdu wynosił 30 minut (podobnie jak dzisiaj), cena biletu $1,2 \mathrm{z}^{45}$.

Gdy w 1935 roku na terenie WMG utworzono nowy PO 5, zaistniała, wprawdzie krótko, wyjątkowa w polskim wywiadzie płytkim sytuacja. W bezpośrednim sąsiedztwie działały trzy posterunki oficerskie: dwa w Gdańsku, jeden w Gdyni. Jeśli dodać do tego gdyński SRI DF, to widać, jak poważnie traktowano w Oddziale II splot nadmorskich spraw.

W zakresie kontrwywiadowczym PO 2 było rodzajem tarczy osłaniającej port w Gdyni i najbliższy rejon przed penetracją niemiecką „idącą” z Wolnego Miasta. Zadania $\mathrm{z}$ tego zakresu przydzielane przez Żychonia pracownikom posterunku były różnorakie - od drobnych i uzupełniających (tych było najwięcej) do prowadzenia skomplikowanych afer (zwykle we współpracy z bydgoską centralą ekspozytury lub gdańskim PO 4). Do łatwych zadań należało namierzanie mieszkań, w których na terenie Wolnego Miasta niemieckie służby spotykały się ze współpracownikami (tzw. lokale konfidencjonalne). Zwykle należało sfotografować budynek z zewnątrz i zrobić plan okolicy ${ }^{46}$. Kilkadziesiąt zadań

\footnotetext{
${ }^{44}$ Byli to: Antoni Kachlicki (majątek Szenfeld, obecnie Nieżychowice w powiecie chojnickim), Ludwik Urbaniak (Żychce, gmina Konarzyny), Stanisław Szóstak (Żychce), Jan Orłowski (Racławki, gmina Chojnice, w pobliżu tranzytowej linii kolejowej) i Stanisław Rybarczyk (Racławki), (Archiwum IPN Bydgoszcz, sygn. 069/137/3, Fotokopia pisma Ekspozytury nr 3 do kierownika PO 2 z 21 X 1937 r.).

${ }^{45}$ Przejazd autobusem trwał około 45 min i kosztował 1,6 zł. Działała też komunikacja lotnicza: z Rumii do Wrzeszcza przelot trwał ok. 20 min, za co trzeba było zapłacić 6 zł (był tylko jeden lot dziennie).

46 Jeden z takich lokali był - cytując polecenie Żychonia - „w Gdańsku przy Hundegasse, idąc od Holzmarkt po lewej stronie w jednym z ostatnich domów przed kanałem (na pierwszym piętrze
} 
rocznie dotyczyło sprawdzenia doniesień posterunków oficerskich, ekspozytury lub innych służb polskich w odniesieniu do podejrzanych osób. Badano zachowania - zwłaszcza gdańszczan - nietypowe i występujące regularnie. Przykładowo, Georg Beherdt, mieszkający na Strandgasse 4 (ul. Dolna) w Gdańsku, był co jakiś czas odwiedzany przez młodą kobietę Zofię, przyjeżdżającą z Grudziądza. Po każdym jej przyjeździe Beherdt wyjeżdżał samochodem do Berlina, zaś po powrocie wysyłał dwóch ludzi do Polski. Mogło chodzić o interesy, przemyt, ale też i o przekazywanie wiadomości, bo Wolne Miasto służby niemieckie i polskie wykorzystywały jako dogodne miejsce spotkań agentów i drogę przepływu meldunków. Żychoń polecił PO 2 poprowadzić sprawę, co też nastąpiło, choć z pewnymi komplikacjami ${ }^{47}$. W 1934 roku posterunek gdyński przepracował ogółem 61 „afer kontrwywiadowczych”, o różnym stopniu złożoności ${ }^{48}$.

Za zadania niższej rangi należy uznać zbieranie wiadomości o powiązaniach między przedsiębiorstwami polskimi, gdańskimi i niemieckimi na Wybrzeżu. Wiele firm niemieckich, zwłaszcza spedycyjnych, morskich, miało siedzibę w WMG i dodatkowo w Gdyni. Jeśli jeszcze utrzymywały one kontakt z polskimi przedsiębiorstwami - oficerowie PO 2 zbierali na ich temat informacje. Zwykle dotyczyły one obsady, obrotów, zakresu działań, wzajemnych powiązań. Centrala ekspozytury oczekiwała też wiadomości o ustosunkowaniu się kierownictwa firmy do Polski, na temat zleceń płynących z Polski i ewentualnych kontaktach z niemieckim wywiadem ${ }^{49}$. W tych sprawach PO 2 często korzystał z cywilnych wywiadowni handlowo-kredytowych, takich jak gdyńska „Balticum” (z siedzibą przy ul. Starowiejskiej 34). Badały one wiarygodność kontrahentów na prywatne zlecenia, ale i przyjmowały zadania od Oddziału II. Jak wynika z dokumentacji, działały one sprawnie i dostarczały szczegółowych informacji.

był skład kapeluszy), na drugim piętrze pokój konfidencjonalny z osobnym wejściem”. Z opisu wynika, że Żychoń nie dysponował adresem, lecz tylko opisem, zapewne pochodzącym od jednego z agentów, który w lokalu owym gościł (CAW, Oddział II SGWP, sygn. I.303.4.6284, Pismo Żychonia do PO 2 z 4 II 1935 r.).

${ }^{47}$ CAW, Oddział II SGWP, sygn. I.303.4.6284, Pismo Żychonia do PO 2 z 16 II 1935 r. Agenta PO 2 nr 1170 (Chojnacki, ps. Fichtner), który w biurze meldunkowym próbował sprawdzić adres zamieszkania Beherta, zatrzymano i przesłuchano, pytając, dlaczego interesuje się jego osobą.

${ }^{48}$ CAW, Oddział II SGWP, sygn. I.303.4.6284, Sprawozdanie z działalności PO 2 Gdynia za rok 1934.

49 Przykładowo w 1935 r. kpt. Lis zbierał wiadomości na temat maklerskiej i spedycyjnej firmy gdańskiej Ferdynanda Prowe „Speditionsgeschäft”, która miała filię w Gdyni (przy Starowiejskiej 6) i prowadziła interesy z Państwową Wytwórnią Prochu i Materiałów Wybuchowych w Pionkach (CAW, Oddział II SGWP, sygn. I.303.4.6284, Pismo Żychonia do PO 2 z 23 II 1935 r.). 
Za podejrzane i godne sprawdzenia uznawano niektóre zachowania Polaków przybywających do Wolnego Miasta. Z Bydgoszczy zlecano PO 2 rozpracowanie osób, które nie zatrzymywały się w hotelach, lecz w domach Niemców. Sprawdzano zakwaterowanych w hotelach znanych jako „giełdy szpiegowskie”. Na celowniku byli osobnicy wypytujący urzędników polskich w WMG o szczegóły ich pracy (zwłaszcza pocztowców, kolejarzy) ${ }^{50}$. Obserwowano tych, którzy uchylając się od zasadniczej służby w Wojsku Polskim, uciekali do Gdańska, gdyż raczej słusznie zakładano, że mając spalone mosty w Polsce, mogą wykonywać różnorakie zadania w WMG (niekiedy zostawali płatnymi konfidentami policji gdańskiej). Poważny odsetek stanowili w tym wypadku obywatele polscy narodowości ukraińskiej i żydowskiej.

Do rutynowych zadań PO 2 należało sprawdzanie znajomości oficerów Wojska Polskiego i członków ich rodzin (zwłaszcza żon). Zwracano uwagę na kontakty z obywatelami niemieckimi i gdańskimi. Sprawdzano subtelne ślady i pogłoski, które mogły być uznane za plotki. Analizowano nawet gesty wskazania na agenta wykonane na dworcu, bo mógł to być ślad rozpowszechniania wiedzy groźnej dla Oddziału II ${ }^{51}$. Sprawdzano też kobiety, z którymi oficerowie i żołnierze (jeśli służyli np. w sztabach) utrzymywali stosunki intymne, słusznie zakładając, że „podsuwanie pań” to jedna z podstawowych metod wyciągania wiadomości i wciągania do współpracy ${ }^{52}$. Działało to oczywiście w obie strony. Pracownicy posterunku sporo uwagi poświęcali kobietom z Gdyni i zwłaszcza z Gdańska, które były prostytutkami lub z różnych powodów (np. bezrobocia,

\footnotetext{
${ }^{50}$ Przykładowo, Żychoń polecił PO 2 sprawdzić Tadeusza Nakoniecznego, vel Jana Jaremiego Woronieckiego, vel Czerwińskiego, ur. 28 XII 1908 r. w Krakowie, rzekomego inżyniera i majora pilota Wojska Polskiego, absolwenta Politechniki Gdańskiej (za takowego podawał się różnym osobom), który podczas rozmów z urzędniczkami pocztowymi starał się od nich wydobyć szkice urządzeń technicznych centrali telefonicznej (CAW, Oddział II SGWP, sygn. I.303.4.6284, Pismo Żychonia do PO 2 z 14 II 1935 r.).

${ }^{51} \mathrm{~W}$ jednym $\mathrm{z}$ meldunków $\mathrm{z}$ tego zakresu kpt. Lis informował na podstawie doniesienia byłego agenta 1133 (Bolesław Pancierzyński), że „pani Nowakowa, żona kpt. 2. Baonu Strzelców wyjeżdża bardzo często do Gdańska oraz że przyjaźni się z niejaką Capeller, obywatelką niemiecką zamieszkałą w Tczewie. Nowakowa przyjaźni się również z żoną byłego por. Jankowskiego, której mąż został zwolniony z wojska, ona zaś mieszka stale przy rodzicach w Gdańsku. Charakterystycznym w tej sprawie jest to, że Nowakowa swego czasu na dworcu w Tczewie wskazała Jankowskiej byłego agenta Pancierzyńskiego" (CAW, Oddział II SGWP, sygn. I.303.4.6284, Pismo Lisa do Żychonia z 26 II 1935 r.).

52 Przykładowo, Żychoń polecił PO 2 sprawdzić 23-letnią stenotypistkę z Gdańska, Walerię Zalewską, ponieważ wymieniona ,utrzymuje z pewnym oficerem WP w kraju kontakt, który może mieć poza tłem erotycznym, również inny podkład" (CAW, Oddział II SGWP, sygn. I.303.4.6284, Pismo Żychonia do PO 2 z 14 V 1935 r.).
} 
kryzysu, wdowieństwa) prowadziły bardzo aktywne życie towarzysko-seksualne. W mieście portowym zapotrzebowanie na podobne „postawy” było spore, a więc i podaż znaczna. Oficerowie odnotowywali owe panie i szukali za ich pośrednictwem dojść do określonych środowisk (np. celników gdańskich). Stosunkowo łatwo było je przekupić lub szantażować, by dostarczały informacji, którymi dzielili się z nimi mężczyźni.

Do zadań PO 2 należało też poszukiwanie osób wskazanych przez gdyński Morski Pluton Żandarmerii na terenie Wolnego Miasta. Żandarmi polscy nie mogli prowadzić działań poza granicami kraju, zwracali się więc z prośbami do szefa ekspozytury bydgoskiej, ten zaś zlecał je kierownikom posterunku gdyńskiego. Z niektórych poszukiwań wynika, że w Wojsku Polskim służyli również obywatele Wolnego Miasta. Gdy więc dezerterowali z jednostek polskich, naturalną koleją rzeczy schronienie znajdowali w Gdańsku, gdzie jurysdykcja w tym zakresie nie sięgała. Pozostawały jedynie działania poufne ${ }^{53}$.

W 1935 roku gdyński PO przeprowadził kilka operacji mających sprawdzić zakres poboru obywateli Wolnego Miasta do niemieckich sił zbrojnych. Przypomnijmy, że 16 marca tego roku rząd niemiecki przyjął krótką, zawierającą trzy artykuły ustawę, której istotą było przywrócenie w Rzeszy powszechnego obowiązku służby wojskowej. To złamanie jednego z zasadniczych założeń systemu wersalskiego zostało dopełnione ustawą z 21 maja, szczegółowo omawiającą kształt Wehrmachtu (z nazwy Reichswehr zrezygnowano, jako oznaczającej armię zawodową i pokłosia „haniebnego pokoju”). Zapisano w niej, że „każdy Niemiec obowiązany jest do pełnienia służby wojskowej”54. Według wykładni nazistowskiej „niemieckość” była pochodną rasy, jej związek z obywatelstwem był nieoczywisty. Tak więc gdańszczanie, niemal w 90\% narodowości niemieckiej, byli według władz Rzeszy Niemcami, którzy powinni służyć w Wehrmachcie, zwłaszcza że według przywołanej ustawy służba wojskowa była „ukoronowaniem wychowania obywatelskiego każdego Niemca"s5. Wychowanie w tym duchu obywateli WMG miało prowadzić do przyszłego włączenia Gdańska do Niemiec (co nastąpiło w 1939 r.). Kapitan Lis otrzymał zadanie zbadania dróg

${ }^{53}$ Przykładowo, w 1935 r. PO 2 rozpoczął poszukiwania w WMG marynarza Roberta Lornatusa, obywatela gdańskiego ur. 22 IX 1901 r., zbiegłego ze służby w Dowództwie Wybrzeża Morskiego w Pucku (CAW, Oddział II SGWP, sygn. I.303.4.6284, Pismo Żychonia do PO 2 z 17 II 1935 r.).

54 J. Benoist-Méchin, Niemcy i armia niemiecka 1918-1938, t. 2, Oświęcim 2015, s. 208.

55 Tamże. 
i zakresu poboru do Wehrmachtu w WMG. Niektóre działania przeprowadził jeszcze przed ukazaniem się ustaw, inne już po ich promulgacji ${ }^{56}$. Schemat był podobny: agent wysyłał prośbę o przyjęcie do wojska adresowaną do Reichswehrministerium, po 2-3 tygodniach pocztą zwrotną otrzymywał z ministerstwa broszurę z instrukcjami (Merkblatt; PO 2 zdobył ją już w lutym 1935 r.). Instrukcja sugerowała złożenie podania do właściwego dowództwa (w przypadku Gdańska - Wehrkreiskommando I w Królewcu). Po mniej więcej dwóch tygodniach agenta wzywano na posterunek policji gdańskiej, gdzie otrzymywał wiadomość, gdzie i kiedy zostanie dokonany pobór. Zwykle następował on wiosną lub jesienią, wcześniej jednak kandydat z WMG musiał pojechać do Berlina, gdzie badano jego zdrowie, wykształcenie i życiorys (był to odpowiednik polskich PKU). Wyjazdy były grupowe, zwykle kilkudziesięcioosobowe. Potem jeszcze raz poborowego wzywano na komisję, tym razem już do Królewca (wyjazdy organizowano autobusami z Gdańska). Procedura trwała długo i nie każdy przechodził ją z pozytywnym rezultatem. Na każdym etapie miejscem koordynującym w Gdańsku były posterunki policji. Kandydatów dość szczegółowo sprawdzano. Agent PO 2 jeszcze raz musiał jechać do Berlina, gdzie przeprowadzano egzamin z wiedzy ogólnej i wiedzy o wojsku niemieckim. W 1935 roku od podania wysłanego w styczniu do wcielenia do jednostki Wehrmachtu w Prusach Wschodnich upływały zazwyczaj cztery miesiące ${ }^{57}$.

Polecenia rozbudowane napływały do PO 2 rzadziej, ale za to absorbowały miesiące. W lutym 1935 roku szef ekspozytury bydgoskiej polecił „rozpracować Schupo [Schutzpolizei - policja ochronna - W.S.] w Gdańsku, przedstawić mi jej organizację, zaszłe zmiany w bieżącym roku oraz skład personalny przy równoczesnym wskazaniu imienia i nazwiska, charakteru służbowego oraz adresu zamieszkania poszczególnych osób"s8. Tego samego miesiąca Żychoń zażądał rozpracowania żandarmerii niemieckiej w Gdańsku. Część danych do takiego opracowania można było zdobyć w wydawnictwach oficjalnych, których Niemcy wydawali wiele (książki adresowe, zestawienia statystyczne, prasa i różnego

${ }^{56}$ Wiosną 1935 r. kpt. Lis zwerbował kandydatów na agentów spośród obywateli gdańskich, którzy mieli wystąpić o powołanie do armii niemieckiej: Dwojacki (ps. Obwexer), Paweł Piernitzki (ps. Trunk) i Wiśniewski (ps. Zander).

${ }^{57}$ CAW, Oddział II SGWP, sygn. I.303.4.6284, Pismo kpt. Lisa do szefa ekspozytury bydgoskiej z 1 VI $1935 \mathrm{r}$.

${ }^{58}$ Tamże, Pismo Żychonia do PO 2 z 18 II 1935 r. 
rodzaju informatory, typu Danziger Beamten-Jahrbuch). Część jednak trzeba było zdobyć metodami wywiadowczymi.

Rok 1935 był przełomowy dla prac PO 2 Gdynia. Nie tylko silniejszy akcent położono na zadania wywiadu ofensywnego. Przemiany nazistowskie w Niemczech i Gdańsku zmieniły charakter i jakość prac kontrwywiadowczych - w niektórych zakresach było łatwiej, w innych trudniej. Porucznik Robak w raporcie z 1936 roku podsumował, że Niemcy zauważalnie zaczęli się lękać kary śmierci za szpiegostwo. Obawiali się też coraz aktywniejszych funkcjonariuszy tajnej policji (Gestapo) oraz członków Sztafet Ochronnych NSDAP (SS), którzy nawet w Wolnym Mieście zaczynali być zauważalną elitą nowych Niemiec, fanatycznie oddaną reżimowi i śledzącą objawy nielojalności ${ }^{59}$. Robak podkreślał, że dla realizacji zadań szpiegowskich przeszkodą jest ,znaczne podniesienie się poczucia godności narodowej od przyjścia do władzy Hitlera". Wśród przemian sprzyjających jego pracom wymienił terror nazistowski wobec innych partii niemieckich, co skłaniało ich członków do współpracy z Polakami; dewaluację guldena gdańskiego i trudną sytuację aprowizacyjną w Rzeszy, co czyniło prace dla Oddziału II opłacalnymi (a czasami koniecznymi do przeżycia); rozbudowę Wehrmachtu i powszechną służbę wojskową (z wymienionych wcześniej przyczyn) ${ }^{60}$.

Głównym obszarem zagranicznej działalności ofensywnej PO 2 była rejencja koszalińska (czyli wschodnie powiaty Pomorza Zachodniego). Szczególnym zainteresowaniem obdarzano umocnienia powstającego wówczas Wału Pomorskiego (Pommernstellung $-d$ l). Zadania te realizowali Zygmunt Najdowski (ps. Henryk Ebner, agent nr 1145) i Jan Kropidłowski (ps. August Freiberg, agent nr 1212), choć nie byli jedynymi, którzy zajmowali się tą kwestią ${ }^{61}$. Najwięcej

\footnotetext{
${ }^{59}$ Zob. J. Daniluk, SS w Gdańsku. Wybrane zagadnienia, Gdańsk 2013.

${ }^{60}$ CAW, Oddział II SGWP, I.303.4.6167, Sprawozdanie kpt. Lisa dla szefa ekspozytury bydgoskiej Oddziału II z 14 II 1936 r.

${ }^{61}$ Wiosną 1935 r. PO 2 wysłało do centrali ekspozytury meldunek zawierający relację cieśli pracującego przy budowie umocnień w okolicach Wałcza. Podobnie jak pozostali robotnicy został on zobowiązany przez niemieckich zleceniodawców wojskowych do zachowania tajemnicy. Prace budowlane prowadzono zawsze za szczelnymi ogrodzeniami, aby osoby postronne nie mogły nic dostrzec. Według jego relacji - do których należy podchodzić z rezerwą - wszystkie jeziora w okolicy Wałcza i na północ aż do morza zostały połączone podziemnymi korytarzami, które zaminowano i połączono przewodami elektrycznymi. W przypadku ataku Polaków ładunki miały zostać zdetonowane, aby zalać teren działań i powstrzymać przeciwnika (CAW, Oddział II SGWP, sygn. I.303.4.6284, Pismo kpt. Lisa do szefa ekspozytury bydgoskiej z 29 III 1935 r.). Latem kpt. Lis otrzymał meldunek agenta „Nast” (prawdopodobnie Franz Nast, ps. Erich Kunst lub Bernhard Nast) mogący potwierdzać to doniesienie. 4 km na północ od Człuchowa, w okolicy Kołdowa, na wschód od szosy wiodącej do Przechlewa Niemcy wybudowali jednopiętrowy dom
} 
agentów ofensywnych PO 2 działało wokół linii miast Słupsk-Miastko-Szczecinek-Złotów-Wałcz. Do 1935 roku działalność PO 2 w tym zakresie była marginesem prac posterunku. Jednak forsowna rozbudowa niemieckich sił zbrojnych, związana z utworzeniem Wehrmachtu, zmieniła ten stan. Dowództwo wojskowe na dużą skalę kupowało majątki na wschodzie Niemiec, by budować na ich obszarze bazy wojskowe ${ }^{62}$. Dla władz wojskowych Polski, a więc i dla Oddziału II, ważniejsze od kontrwywiadu było rozpracowanie sił zbrojnych Trzeciej Rzeszy. Agenci PO 2 coraz częściej dostarczali wiadomości z powiatów leżących poza rejencją koszalińską, głównie na obszarze północnych powiatów Marchii Granicznej Poznań-Prusy Zachodnie (Człuchów, Złotów, Wałcz, Piła). W tym zakresie również sąsiedztwo Wolnego Miasta rodziło specyficzne możliwości. Kierownicy PO 2, bazując na tym, że Niemcy bez problemów przyjmowali do Wehrmachtu również obywateli WMG, starali się nakłaniać agentów tam mieszkających do poddania się nielegalnemu poborowi (np. Helmut Raczyński, ps. Wilhelm Altenburg).

Kierownicy PO 2 nawiązali stałą współpracę z komendantami policji w Kościerzynie, Sępólnie Krajeńskim, Starogardzie Gdańskim oraz z Wydziałem Bezpieczeństwa Komisariatu Rządu w Gdyni przy werbowaniu przyjeżdżających do Polski na urlop urzędników niemieckich. Podczas prac operacyjnych dużą pomocą służyli funkcjonariusze Wydziałów Śledczych Policji Państwowej w Gdyni i Tczewie oraz północno-pomorskie placówki Straży Granicznej. Na trudności natrafiała współpraca z kierownikiem komisariatu gdyńskiego PP. Specyfika miasta portowego umożliwiała współpracę w werbunku z innymi instytucjami. Przykładowo, kandydatów na informatorów wskazywali pracownicy Urzędu Celnego i dyrektor Polsko-Skandynawskiego Towarzystwa Transportowego „Polskarob” Czesław Raczewski (będący również wicekonsulem honorowym Hiszpanii).

i dwa mniejsze obiekty betonowe, przypominające schrony. Dom o rozmiarach $12 \times 8 \mathrm{~m}$, kryty czerwoną dachówką, zamieszkali dwaj mężczyźni nieznani nikomu w okolicy. Schrony o wymiarach 4 x 2,5 m i 5 x 4 m miały stropy z betonu o grubości $90 \mathrm{~cm}$, wzmocnione płytami pancernymi oraz żelazne drzwi. Do posesji, szczelnie ogrodzonej, doprowadzono kabel o grubości $2 \mathrm{~cm}$. W najbliżej okolicy znajdowały się rzeki, kanały i jeziora. Kpt. Lis przypuszczał, że budynek mógł być stacją podsłuchową wojska (CAW, Oddział II SGWP, I.303.4.6284, Pismo kpt. Lisa do szefa ekspozytury bydgoskiej Oddziału II z 15 VII 1935 r.).

${ }^{62} \mathrm{O}$ budowie takiej bazy $2 \mathrm{~km}$ na północny wschód od Wałcza (wówczas majątek Johannistahl) informował kpt. Lis w połowie 1935 r. Majątek kupił Wehrmacht za 480 tys. marek i rozpoczęto budowę koszar i bunkrów (CAW, Oddział II SGWP, I.303.4.6284, Pismo kpt. Lisa do szefa ekspozytury bydgoskiej Oddziału II z 31 VII 1935 r.). 
Do zadań PO 2 należała ochrona kontrwywiadowcza instytucji polskich w Gdyni, głównie przed działaniami mającymi źródło w Gdańsku. W typowym meldunku z tego zakresu kpt. Lis informował swojego przełożonego, kpt. Żychonia, że

w ostatnich czasach przyjeżdżają dość często różni funkcjonariusze kryminalnej policji gdańskiej do Wydziału Śledczego ${ }^{63} \mathrm{w}$ Gdyni w różnych służbowych sprawach. Ostatnio w dniu 21 I br. [1935] przyjechał do Kierownika Wydziału Śledczego w Gdyni komisarz policji kryminalnej Malek ${ }^{64}$, znany Ekspozyturze, który przyniósł 5 kart wstępu do Kasyna in blanco, jako prezent policji gdańskiej dla policji w Gdyni. Równocześnie proponował Malek Kierownikowi Wydziału Śledczego pójście gdzieś na wódkę, od czego Kierownik Wydziału Śledczego wymówił się.

Dalej Lis sugerował, że skoro policjanci Wydziału Śledczego pośredniczą w różnych działaniach Oddziału II (np. inspirowaniu wywiadu niemieckiego), Abwehra pragnie tym sposobem zinfiltrować ten obszar ${ }^{65}$.

Kasyno w Sopocie było miejscem szczególnym. Bywało tam wielu Polaków, również urzędników państwowych i byłych oficerów Wojska Polskiego. Na miejscu był lombard, gdzie gracze zastawiali zegarki, biżuterię, cokolwiek posiadali cennego, i niejednokrotnie opuszczali budynek całkowicie bez środków do życia. Samobójstwa nie należały do rzadkości, ale niektórzy desperaci wybierali inne wyjście, na przykład przyjmowali propozycję pożyczki pochodzącą od werbunkowych obcych służb. Oznaczało to początek szantażu, ale czasem obywało się i bez niego. Skuszeni „łatwymi” dochodami, uzależnieni od hazardu, zostawali agentami. Z tego powodu praktycznie wszyscy znaczniejsi Polacy - goście kasyna byli sprawdzani pod kątem kontrwywiadowczym. Wprowadzono też regulacje prewencyjne ${ }^{66}$. Co najmniej od 1936 roku pracownicy Oddziału II podpisywali

${ }^{63}$ Wydziały Śledcze działały przy większych miejskich i powiatowych komendach Policji Państwowej. Odpowiadały za prowadzenie śledztw pod nadzorem sądów i prokuratur. W ich gestii leżały sprawy kryminalne, ale i polityczne (np. inwigilacja nacjonalistów ukraińskich, komunistów) oraz w pewnym stopniu kontrwywiadowcze. W 1933 r. w Gdyni w Wydziale Śledczym pracowało 26 funkcjonariuszy, w tym 2 oficerów.

${ }^{64}$ Zapewne chodziło o komisarza Bruna Malecka.

${ }^{65}$ CAW, Oddział II SGWP, I.303.4.6284, Pismo kpt. Lisa do szefa ekspozytury bydgoskiej Oddziału II z 22 I 1935 r.

${ }^{66}$ Z Bydgoszczy do Gdyni przeprowadził się porucznik w stanie spoczynku Stefan Chlebowski, dawniej służący w 8 Dyonie Samochodów. Zaczął bywać w sopockim kasynie i tam zauważyli go agenci PO 2. Wniosek Żychonia był następujący: „Wobec tego, że por. Chlebowski bywając obecnie gościem Kasyna Gry Zoppot może być obrobiony przez wywiad niemiecki - wysuwam 
zobowiązanie, że nie będą tam uczęszczać w celu gry ${ }^{67}$. Również minister spraw zagranicznych wydał poufny zakaz wizyt wszystkim swoim podwładnym. Zignorowanie zakazu było traktowane jak złamanie obowiązków służbowych, powodujące obrazę interesu publicznego, i było surowo karane. Każdy urzędnik MSZ potwierdził podpisem przyjęcie zakazu do wiadomości ${ }^{68}$. Dla PO $2 \mathrm{w}$ kasynie sopockim pracowało ogółem kilku agentów (np. Gertuda Lukanowska).

Od 1935 roku pracownicy PO 2 prenumerowali fachową prasę gospodarczo-morską ukazującą się w portach niemieckich Emden, Bremie, Lubece i Hamburgu $^{69}$. W celu ukrycia rzeczywistego odbiorcy prenumeratę opłacano poprzez Polską Agencję Morską (z siedzibą na ul. Świętojańskiej w Gdyni), której dyrektor służył też fachowymi radami przy interpretacji niektórych wiadomości. Ten klasyczny wywiad biały był częścią rodzącego się z niejakim opóźnieniem i mozołem wywiadu morskiego Rzeczypospolitej ${ }^{70}$. W dalej idących działaniach z tego zakresu oficerowie PO 2, jak się wydaje, nie uczestniczyli. W 1935 roku Żychoń poinformował ich, że w imieniu Oddziału II wywiad gospodarczy z tego zakresu realizuje Biuro Wojskowe przy Ministerstwie Przemysłu i Handlu w Warszawie. Działało ono za pośrednictwem biur Polskiej Agencji Informacji Handlowej, zbierających na zlecenie wiadomości w różnych krajach i przekazujących je do stolicy. Żychoń poprosił o założenie takiego biura w Gdyni. Z jego poduszczenia do Warszawy wezwano dyrektora gdyńskiego Urzędu Morskiego, Stanisława Łęgowskiego, gdzie miał otrzymać ustne instrukcje nakazujące mu współpracę z ekspozyturą bydgoską w zakresie wywiadu morskiego oraz życzliwe ustosunkowanie się wobec oficerów Oddziału II, którzy będą się do niego zgłaszać po informacje $\mathrm{i}^{71}$. Żychoń oczekiwał sprawozdań z „wywiadu morskiego”,

koncepcję ewentualnego uprzedzenia tego faktu i wykorzystania go w pracy PO jako inteligentnego agenta na terenie Kasyna”. Była to sugestia, ale w praktyce polecenie. Zwyczajowo pod koniec pismo padło zdanie, że szef ekspozytury oczekuje na opis załatwienia tej sprawy w raporcie organizacyjnym PO 2 (CAW, Oddział II SGWP, I.303.4.6284, Pismo Żychonia do PO 2 z 8 IV 1935 r.).

${ }^{67}$ CAW, Oddział II SGWP, sygn. I.303.4.6167, Lista pracowników PO 2 w Gdyni z 8 X 1936 r.

${ }^{68}$ Archiwum Akt Nowych, Poselstwo RP w Budapeszcie, sygn. 257, Pismo ministra spraw zagranicznych do szefów jednostek organizacyjnych z 1 VIII $1936 \mathrm{r}$.

${ }^{69} \mathrm{CAW}$, Oddział II SGWP, 6284, Pismo kpt. Lisa do szefa ekspozytury bydgoskiej Oddziału II z 28 II 1935 r.

${ }^{70}$ Zob. R. Majzner, Wywiad morski II Rzeczypospolitej (1918-1939), „Zeszyty Historyczne” 2016 (wydawane przez Akademię im. Jana Długosza w Częstochowie), t. 15, s. 207-230.

${ }^{71}$ CAW, Oddział II SGWP, sygn. I.303.4.6284, Pismo Żychonia do PO 2 w sprawie wywiadu morskiego z 16 II $1935 \mathrm{r}$. 
prowadzonego za pośrednictwem ideowych (nieopłacanych) informatorów z kręgów polskiej administracji morskiej i załóg statków, od wiosny 1935 roku $^{72}$. Sieć taką zorganizował kpt. Lis do połowy czerwca tego roku ${ }^{73}$.

Posterunek wywiadowczy w Gdyni był dobrze działającym trybem polskiej maszyny wywiadowczej skierowanej przeciwko nazistowskim Niemcom. Jego prace spotykały się zwykle z dobrą oceną Żychonia i przełożonych w Warszawie. Personel PO 2 znacząco przyczynił się do rozpracowania niemieckich przygotowań wojennych w Gdańsku i wschodnich prowincjach Trzeciej Rzeszy. Ogólnie pozytywne podsumowanie w skali lokalnej burzy jednak wiedza o tym, że zarówno władze wojskowe, jak i cywilne Polski w niewielkim stopniu chciały (i potrafiły) zużytkować dostarczaną wiedzę. W niewielkim też stopniu wiedza wywiadu o miażdżącej przewadze Trzeciej Rzeszy przedostawała się do społeczeństwa polskiego, przekonanego - cytując ówczesne hasła propagandowe i wypowiedzi - że jesteśmy ,silni, zwarci, gotowi” i ,nie oddamy nawet guzika". O sensie pracy wywiadu przesądza bowiem nie tylko rzetelność zebranych wiadomości o przeciwniku, ale i gotowość do ich uwzględnienia przez własne władze.

\section{Bibliografia}

\section{Źródla archiwalne}

Archiwum Akt Nowych, Poselstwo RP w Budapeszcie

Archiwum Instytutu Pamięci Narodowej w Warszawie

Archiwum Instytutu Pamięci Narodowej w Bydgoszczy

Centralne Archiwum Wojskowe w Rembertowie, Oddział II Sztabu Głównego WP

Prasa

„Słowo Pomorskie”

\section{Źródla drukowane}

Katyń. Dokumenty zbrodni, t. 3, Losy ocalatych: lipiec 1940 - marzec 1943, oprac. W. Materski, Warszawa 2001.

Rocznik Morski i Kolonialny 1938, Warszawa 1938.

Rocznik Statystyczny Gdyni 1933-1934, red. B. Polkowski, Gdynia 1934.

\footnotetext{
72 Tamże, Pismo Żychonia do PO 2 i 4 w sprawie wywiadu morskiego z 6 II 1935 r.

${ }^{73}$ Tamże, Pismo kpt. Lisa do szefa ekspozytury bydgoskiej Oddziału II z 17 VI 1935 r.
} 


\section{Wspomnienia i reportaże}

Rummel J., Sen o Gdyni, w: Brama na świat. Gdynia 1918-1939, oprac. M. Rdesiński, Gdańsk 1976.

Walicka M., Gdynia. Pejzaż sprzed wojny, Gdańsk 1982.

Wańkowicz M., Judym na szczeblu stużbowym, w: Brama na świat. Gdynia 1918-1939, oprac. M. Rdesiński, Gdańsk 1976.

Wat A., Mój wiek. Pamiętnik mówiony, t. 2, Warszawa 1990.

\section{Opracowania}

Benoist-Méchin J., Niemcy i armia niemiecka 1918-1938, t. 2, Oświęcim 2015.

Daniluk J., SS w Gdańsku. Wybrane zagadnienia, Gdańsk 2013.

Dąbrowski D., Rzeczpospolita Polska wobec kwestii Rusi Zakarpackiej (Podkarpackiej) 1938-1939, Toruń 2007.

Dubicki T., Suchcitz A., Oficerowie wywiadu WP i PSZ w latach 1939-1945. Słownik biograficzny, t. 1, Warszawa 2009; t. 2, Warszawa 2011.

Gondek L., Wywiad polski w III Rzeszy 1933-1939. Zarys struktury, taktyki i efektów obronnego działania, Warszawa 1982.

Jastrzębski W., Major Żychoń i bydgoska ekspozytura wywiadu, Bydgoszcz 1994.

Kardas M., Gdynia i jej władze w latach 1926-1950. Główne problemy polskiej administracji publicznej miasta, Toruń 2013.

Lis J., Geneza tworzenia Polskich Sił Zbrojnych w ZSRR, „Niepodległość” 1948.

Majzner R., Organizacja i funkcjonowanie kontrwywiadu morskiego (SRI Dowództwa Floty) w latach 30. XX w. na przykładzie zwalczania niemieckiego szpiegostwazarys problematyki, w: Kontrwywiad II RP 1918-1945 (1948), t. IV, red. A. Przyborowska, Warszawa 2017.

Majzner R., Wywiad morski II Rzeczypospolitej (1918-1939), „Zeszyty Historyczne” 2016 (wydawane przez Akademię im. Jana Długosza w Częstochowie), t. 15.

Paduszek K., Zajrzeć do mózgu Lenina. Wywiad II Rzeczypospolitej a postrewolucyjna Rosja, Łomianki 2016.

Przegiętka M., Zainteresowanie wywiadu polskiego niemieckim wojskowym tranzytem kolejowym przez Pomorze w okresie międzywojennym, w: Studia nad wywiadem i kontrwywiadem Polski w XX wieku, t. 2, red. W. Skóra, P. Skubisz, Szczecin 2015.

Skóra W., Działalność gdańskiej ekspozytury polskiego wywiadu wojskowego w latach 1920-1930 (Pomorze Zachodnie, Prusy Wschodnie i Wolne Miasto Gdańsk), Poznań 2011.

Skóra W., Oficerowie wywiadu polskiego na Pomorzu 1919-1939. Sylwetki, kryteria doboru, prawidłowości, w: Kadry decydują o wszystkim. Studia z zakresu biografistyki wojskowej, red. J. Jędrysiak, D. Koreś, G. Strauchold, K. Widziński, Wrocław 2015 . 
Skóra W., Placówki wywiadu polskiego w Chojnicach. Przyczynek do dziejów Pomorza Zachodniego i Nadwiślańskiego w dwudziestoleciu międzywojennym, Poznań 2011.

Stępniak H., Ludność polska w Wolnym Mieście Gdańsku 1920-1939, Gdańsk 1991.

Tym W., Rzepniewski A., Przygotowania do obrony rejonu Gdyni przez sity Ladowej Obrony Wybrzeża, w: Gdynia 1939. Relacje uczestników walk lądowych, oprac. W. Tym, A. Rzepniewski, Gdańsk 1979.

Ulatowski Ł., Polski wywiad wojskowy w 1939 roku. Struktura organizacyjna, składy osobowe, personel, budzet, mob., Warszawa 2013.

Widernik M., Rozwój miasta Gdyni w latach 1926-1939, w: Gdynia wczoraj 1926-1986. 60 lat Gdyni, Gdynia 1986.

Wolsza T., Katyń to już na zawsze katy i katowani. W „polskim Londynie” o sowieckiej zbrodni w Katyniu (1944-1956), Warszawa 2008.

\begin{abstract}
Abstrakt
W Gdyni w latach 1933-1939 działała placówka polskiego wywiadu wojskowego. Był to Posterunek Oficerski nr 2 (PO 2), podlegający większej agendzie, Ekspozyturze nr 3 Oddziału II Sztabu Głównego Wojska Polskiego. Pod kierownictwem oficera pracowało w nim kilku wojskowych i cywilów. Podlegali im agenci, zbierający wiadomości w terenie. Ich liczba oscylowała między 6 a 13. Ogółem w latach 1933-1938 dla PO 2 pracowało w Gdańsku i Niemczech co najmniej 37 agentów.

PO 2 utworzono kilka miesięcy po objęciu władzy w Rzeszy przez nazistów i tuż po wystąpieniu Niemiec z Ligi Narodów. Lata 1931-1933 były okresem wyjątkowego napięcia w stosunkach polsko-gdańskich. Ich widownią było głównie forum Ligi Narodów. Prawdopodobnie powołanie posterunku kontrwywiadu ofensywnego (bo taki miał profil działalności przez pierwsze dwa lata) spowodowane było obawą przed rozwojem sytuacji w Wolnym Mieście. Naziści byli nieobliczalni, a przez to groźni.

W zakresie kontrwywiadowczym PO 2 był tarczą osłaniającą port w Gdyni i najbliższy rejon przed penetracją niemiecką. Sąsiedztwo Wolnego Miasta Gdańska było główną przyczyną powołania posterunku. Było to miasto „,cieplarniane” dla działalności szpiegowskiej i nielegalnej. Przybywali tam dezerterzy, przemytnicy, fałszerze, pospolici przestępcy, działacze polityczni i uciekinierzy przed prześladowaniami.

Do listopada 1935 roku gdyński PO 2 koncentrował się na pracach kontrwywiadowczych związanych z Gdańskiem. Do łatwych zadań należało namierzanie mieszkań, w których niemieckie służby spotykały się ze współpracownikami. Kilkadziesiąt zadań rocznie dotyczyło sprawdzenia doniesień posterunków oficerskich, ekspozytury lub innych służb polskich w odniesieniu do podejrzanych osób. Szukano szpiegów i zdrajców.
\end{abstract}


Badano zachowania - zwłaszcza gdańszczan - nietypowe i występujące regularnie. Zbierano wiadomości o powiązaniach między przedsiębiorstwami polskimi, gdańskimi i niemieckimi na Wybrzeżu. Sprawdzano kontakty towarzyskie oficerów Wojska Polskiego i członków ich rodzin (zwłaszcza żon).

Od 1935 roku, w związku z powstaniem niemieckiej armii z poboru powszechnego (Wehrmacht), PO 2 został przestawiony na działania ofensywne, głównie na terenie Pomorza Zachodniego (czyli wschodniego obszaru Provinz Pommern oraz Grenzmark Posen Westpreussen). Chodziło o poznanie stanu niemieckich zbrojeń, dyslokacji wojsk, budowy lotnisk i umocnień (na późniejszym tzw. Wale Pomorskim - Pommernstellung d 1). I przewidzenie szybkości mobilizacji.

\title{
"A Window ON The World" ANd "Number Two". The Activity of the Polish Military Intelligence and Counter-Intelligence Post in Gdynia In the Years 1933-1939
}

\begin{abstract}
In the years 1933-1939 in Gdynia there was a post of Polish military intelligence. It was an officers' Post no 2 (PO-2), subordinated to a bigger agency, the Branch Office no 3 of the Second Department of the Polish Army's General Staff. An officer managed a team of several people, military men and civilians. In turn, they managed agents, who collected information. Their number oscillated between 6 and 13. Altogether, in the years 1933-1938 there were at least 37 agents working for PO-2 in Gdańsk and Germany.

PO-2 was created a few months after the Nazis assumed power in the Reich and just after Germany left the League of Nations. The years 1931-1933 were a period of exceptional tension between Poland and Gdańsk/Danzig. It was especially visible in the forum of the League of Nations. The reason behind creating a post of offensive counter-intelligence (such was the profile of the post for the first two years) was a fear of how the situation in the Free City of Danzig might develop. The Nazis were unpredictable and dangerous.

From the counter-intelligence point of view PO-2 was a shield protecting the port in Gdynia and its surroundings from the German penetration. The vicinity of Gdańsk was the main reason to create the post. It was a propitious city for espionage. The Free City of Gdańsk/Danzig was full of deserters, smugglers, forgers, common criminals, political activists, escapees and refugees.

Until November 1935 the Gdynia PO-2 concentrated on counter-intelligence concerning Gdańsk. A relatively easy task was to identify flats where the Germans met with their collaborators. Several score of tasks were related with checking the reports concerning various people; the reports were coming from the officers' posts, the branch office or
\end{abstract}


other sources. Spies and traitors were looked for. The behaviours of selected inhabitants of Gdańsk were investigated, especially the uncharacteristic and - at the same time regular ones. The information was collected on the connections between Polish, Gdańsk and German enterprises. Social contacts of officers of the Polish Army and the members of their families (especially their wives) were looked at carefully.

Since 1935 in connection with creating Wehrmacht out of compulsory conscription PO-2 changed its mode of action into offensive, mainly in West Pomerania, i.e. the eastern part of Provinz Pommern and Grenzmark Posen Westpreussen. The point was to define the state of the German armaments, the deployment of German troops, the location of their airports and fortifications (of what was to become the Pomeranian Embankment, Pommernstellung) and the speed of mobilisation. 